\title{
Are Famine Food Plants Also Ethnomedicinal Plants? An Ethnomedicinal Appraisal of Famine Food Plants of Two Districts of Bangladesh
}

\author{
Fardous Mohammad Safiul Azam, Anup Biswas, Abdul Mannan, Nusrat Anik Afsana, \\ Rownak Jahan, and Mohammed Rahmatullah
}

Department of Biotechnology \& Genetic Engineering, Faculty of Life Sciences, University of Development Alternative, House No. 78, Road No. 11A (new), Dhanmondi, Dhaka 1209, Bangladesh

Correspondence should be addressed to Mohammed Rahmatullah; rahamatm@hotmail.com

Received 27 November 2013; Revised 30 December 2013; Accepted 6 January 2014; Published 20 February 2014

Academic Editor: Menaka C. Thounaojam

Copyright (C) 2014 Fardous Mohammad Safiul Azam et al. This is an open access article distributed under the Creative Commons Attribution License, which permits unrestricted use, distribution, and reproduction in any medium, provided the original work is properly cited.

\begin{abstract}
Plants have served as sources of food and medicines for human beings since their advent. During famines or conditions of food scarcity, people throughout the world depend on unconventional plant items to satiate their hunger and meet their nutritional needs. Malnourished people often suffer from various diseases, much more than people eating a balanced diet. We are hypothesizing that the unconventional food plants that people eat during times of scarcity of their normal diet are also medicinal plants and thus can play a role in satiating hunger, meeting nutritional needs, and serving therapeutic purposes. Towards testing our hypothesis, surveys were carried out among the low income people of four villages in Lalmonirhat and Nilphamari districts of Bangladesh. People and particularly the low income people of these two districts suffer each year from a seasonal famine known as Monga. Over 200 informants from 167 households in the villages were interviewed with the help of a semistructured questionnaire and the guided field-walk method. The informants mentioned a total of 34 plant species that they consumed during Monga. Published literature shows that all the species consumed had ethnomedicinal uses. It is concluded that famine food plants also serve as ethnomedicinal plants.
\end{abstract}

\section{Introduction}

Human beings need food for survival and to satiate their hunger. Plants have always constituted a major food source for people throughout the world since the advent of humans. During times of natural disasters like inclement weather conditions, populations suffering from severe food shortages become heavily reliant on wild food plants for survival [1]. This has given rise to the concept of famine plants [2]. Rodale and Mcgrath [3] stated that famine plants have been eaten and utilized for centuries. Certain "wild-foods" are enjoyed and therefore collected and consumed every time when ready and these are important "famine-foods" during periods of food shortage [4].

The human population of the western Sahel has been reported to depend on a number of wild plant foods, and this dependency increases during drought conditions [5]. However, scarcity of food or in practicality, famine condition, is also a common occurrence with people who live in poverty and so cannot afford their daily requirements of a normal and conventional diet. Such food scarcity/famine (famine and food scarcity have been considered equivalent in this paper in the sense that both conditions lead to inadequate intake of daily conventional food items) can be observed among the people of Bangladesh, about a third of those who live below the poverty level income, defined as less than US\$ 1 per day. Moreover, people of the northern districts of Bangladesh are subjected each year to a seasonal famine known as Monga. Monga usually occurs twice a year; the greater Monga (boro Monga) occurs during the lean season preceding the harvest of paddy in the Bangla months of Ashwin and Kartik (mid-September to mid-November), and 
the smaller Monga (choto Monga) occurs during the lean season preceding the harvest of paddy in between the Bangla months of Chaitra and Jaistha (mid-March to mid-June). It is to be noted that rice (obtained after dehusking paddy) is the staple cereal of the people of Bangladesh and is the major item consumed by the poorer rural people with lentils and an occasional sidedish of a vegetable. Monga occurs due to a number of factors, lack of adequate water supply during the above months and lack of diversification of jobs (most people being agricultural laborers with little cultivable land of their own). The agricultural laborers, landless farmers, and the marginal farmers suffer from acute food shortage during Monga [6].

Lalmonirhat and Nilphamari districts are two districts in the northern part of Bangladesh, which suffer from Monga. The people in these districts, particularly the rural poor, are the worst sufferers and suffer during Monga from acute food shortages. We have previously shown that a number of nonconventional plant items are consumed by the poor people of the northern districts of Bangladesh during Monga [7]. In fact, such consumption of nonconventional plant items during times of food scarcity has been reported by us for other districts of Bangladesh, like Rangamati and Kurigram $[8,9]$; Rangamati district does not suffer from Monga, but food scarcity exists among segments of the mainstream population as well as tribal people. Also notably, Rangamati district is in the southeastern portion of the country. During our survey in Kurigram district on famine food plants, we noted a distinct correlation between nonconventional plants consumed during food scarcity and their folk medicinal usage; in other words, most of the plants consumed had folk medicinal uses [10].

Chronic lack of food causes the people to suffer from malnutrition with consequent wasting away of body and weakening of the body's immune systems [11]. This can cause a number of diseases to occur because of the body's weak defenses against invading pathogens. Lack of proper diet can not only cause shortage of macronutrients like carbohydrates, proteins, and lipids, but also cause lack of vitamins and essential micronutrients with concomitant arising of ailments like anemia, night blindness, beriberi, pellagra, kwashiorkor, and marasmus, to name only a few. Thus nonconventional food items should not only be edible, but also satiate the hunger and meet the body's nutritional needs adequately.

The Australian Aboriginal hunter-gatherers reportedly used to have over 800 plant foods, and that this traditional diet may have been low in carbohydrates but high in fiber, leading to protection of the Aborigines from a genetic predisposition to insulin resistance (a physiological condition in which the natural hormone, insulin, becomes less effective in lowering blood sugars) and its consequences like diabetes mellitus, coronary heart disease, and obesity [12]. These conventional food plants and medicine are interrelated as also been shown by other authors. Research in several regions has illustrated that many wild plants that are retained in local food cultures are inseparable from traditional therapeutic systems $[13,14]$. Since ancient times, the thinking of "food as medicine" has existed in Chinese medical theories and Chinese food therapy $[15,16]$. Etkin and Ross $[17,18]$ showed from their West African research that many wild plants were used both in therapeutics and for dietary purposes. We further hypothesize that through trial and error, the human population have selected famine food plants items, which not only fulfill hunger satiating and nutritional needs, but also serves a therapeutic purpose. It then follows from our hypothesis that famine food plants, in general, must also have ethnomedicinal uses.

The objective of the present survey was to conduct an ethnomedicinal appraisal of famine food plants consumed by poor villagers in four villages (Sailmari, Khurdobichondoi, Paschim Dewwabar, and Schatunama) of two adjoining districts, namely, Lalmonirhat and Nilphamari, which are two of the most Monga-prone districts in Bangladesh, and have substantial segments of the population suffering from food scarcity during Monga. The two districts are bordered on the south by Rangpur district, on the north by West Bengal State of India, on the east by Kurigram district, and on the west by Dinajpur and Panchagarh districts (Figure 1). The area of the four villages where the present survey was carried out approximates 50 square kilometers. An indigenous community, namely the Santals, inhabits portions of the two districts covered. The Santals are considered to be original settlers in this area since prehistoric times; however, the majority of the population (over 98\%) of the two districts at present comprises of mainstream Bengali-speaking population.

The villages surveyed lacked any industry; as a consequence, the people are dependent on agriculture. Three of the villages Sailmari, Khurdobichondoi, and Paschim Dewwabar fell under Kaliganj and Hatibandha Upazilas (subdistricts) of Lalmonirhat district, while Schatunuma fell under Dimla Upazila of Nilphamari district (Figure 1). As per National Information Services provided by the Government of Bangladesh [19], the total population of Kaliganj and Hatibanda Upazilas was 216,868 and 239,568, respectively with a literacy rate of 24 , and $21.4 \%$ (it is to be noted that a person is considered literate in Bangladesh if the person can only sign his or her name without even going to primary school). The total population of Dimla Upazila is 280,076 with an average literacy level of $42.86 \%$. Small farmers (i.e. farmers without land or having less than one-third acre of land per family) constituted over $80 \%$ of the population in the villages surveyed; these farmers mostly worked as agricultural laborers in other people's land.

The surveyed villages did not have any forest land. The villages, however, contained fallow land and "char" (river islands on the Teesta River) areas. There was some vegetative cover in the fallow lands and chars; the vegetation mostly consisted of wild herbs, shrubs, and a few trees, which were tropical and subtropical in nature.

\section{Methods}

2.1. Study Area and Investigative Methods. The present survey was conducted between October 2010 and August 2012. A preliminary survey was conducted among the villagers of a number of villages in Lalmonirhat and Nilphamari districts, which according to news reports of the country have a substantial number of households, who were affected 


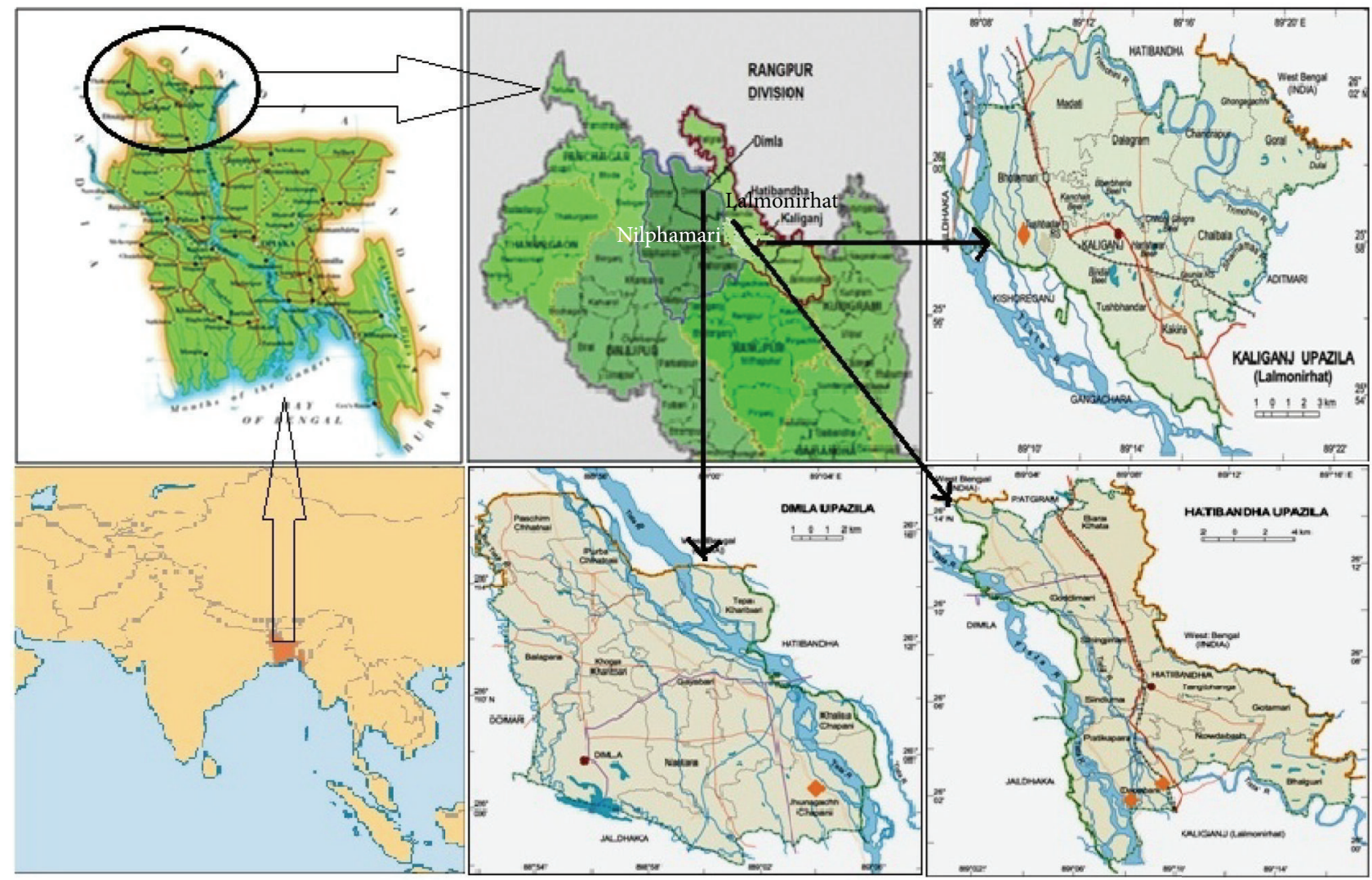

Figure 1: Map of Bangladesh showing the districts, Upazilas, and study sites (villages). Actual study sites are marked on the map as

by Monga. From this preliminary survey, four villages as mentioned above were chosen in the two districts on the basis of the number of households, whose incomes were below the poverty level, and as a consequence, were more affected by Monga. More detailed surveys (comprising of a total of nine visits, each visit lasting four days on an average) were conducted in these four villages among a total of 167 households who mentioned that they consume nonconventional plant items not only during Monga, but also at other times of food scarcity, caused due to their low income levels. All together, 238 adult members ( 219 females and 19 males) from these households were interviewed. It is to be noted that women, particularly the adult married women members of rural households, are in general responsible for cooking food and collecting nonconventional plant items (during times of food scarcity) and so possess more information on famine foods than the male members of the household. Although collecting nonconventional edible plants from the wild or fallow lands and roadsides is also shared by children along with adult female members of the household, such children were not interviewed in the present survey.

2.2. Mode of Interview and Plant Specimen Collection. Informed consent was first obtained from the Head of each household (in most cases being the oldest active male member) to gather information on their monthly income levels, availability of adequate food throughout the year, prevalence of diseases, occupation, literacy, consumption of nonconventional plant food items during times of food scarcity in their households, and the therapeutic uses of the nonconventional plant species. The male Heads of households themselves suggested that information on consumption of nonconventional plants be gathered from the female adult members of each household. Information was collected and recorded with the help of a semistructured questionnaire, open-ended interviews, and the guided field-walk method of Martin [20] and Maundu [21]. In this method, the women informants took the interviewers on guided field walks through areas from where they usually collected their nonconventional edible plants, pointed out the plants, and described the mode of consumption of these plants and the plant parts used for consumption, as well as medicinal values of the plants. All such plant specimens were collected from the spot, pressed, dried [22], and brought back to Dhaka for complete identification by the Bangladesh National Herbarium. Voucher plant specimens were deposited with the Plant Collection Wing of the University of Development Alternative. Nomenclature of plants was compiled from the Plant List database (http://www.theplantlist.org/). Lalmonirhat and Nilphamari are adjoining districts, and it was noticed that the pattern of consumption of nonconventional plants was basically the same for each household in all four villages of the two districts. 


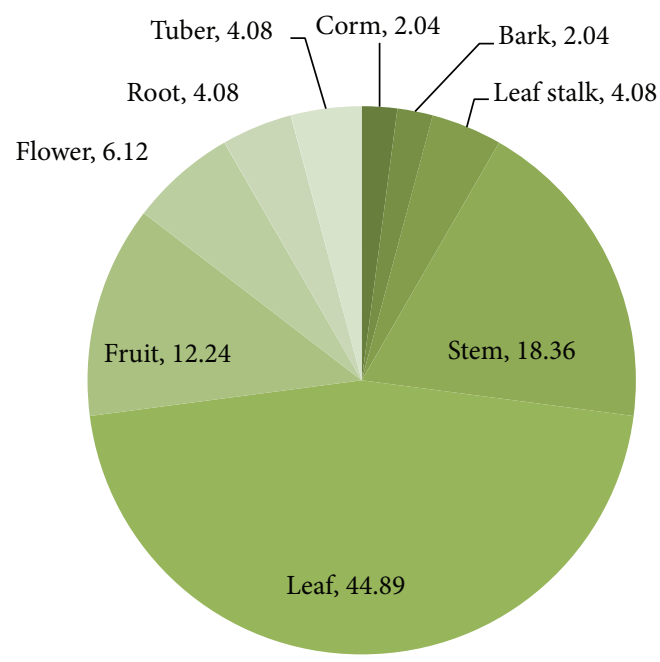

FIGURE 2: Percentage distribution of various plant parts consumed during times of food scarcity.

2.3. Search of Databases for Ethnomedicinal Uses of Plants. Ethnomedicinal uses of the plant reports were collected through searching various databases like PubMed, SCOPUS, and Google Scholar.

\section{Results and Discussion}

3.1. Demographic Characteristics. Of the 219 females interviewed, 76 females $(34.7 \%)$ were in the age group of $21-30$ years, 88 females $(40.2 \%)$ were in the age group of $31-40$ years, and 55 females $(25.1 \%)$ were in the age group of $41-50$ years. $100 \%$ of the females were married and described their occupation as housewives. The literacy rate among the females was $3.1 \%$. Of the 19 males interviewed, 16 males $(84.2 \%)$ described their occupation as agricultural laborers, while 3 males (15.8\%) described themselves as small farmers with land holding not exceeding $1 / 3$ acres. Literacy rate among the interviewed males was $7.9 \%$. It may be noted that the literacy rate among the surveyed population was observed to be lower than the Upazila average. The informants mentioned that part of this lower literacy rate was due to age, for only recently the Government of Bangladesh has made primary education (up to Grade V) compulsory for both males and females. The other factor mentioned by the informants was that they could not even send children to schools regularly because the children were often engaged in foraging for wild edible plants because of chronic food shortages.

3.2. General Dietary Information. According to all informants, their main diet during food availability consisted of rice, which was consumed along with lentil soup (dal), vegetables, and occasionally fish or meat. Since rice contains very low amount of protein, lentils served as the main protein source in the absence of meat or fish items. During times of food scarcity, rice could not be afforded, and so they consumed nonconventional edible plants or plant parts along with lentil soup, if the latter could be afforded. Various types of lentils (pulses) are available in Bangladesh, the most costly being Lens esculenta and Lens culinaris (masoor dal) and Vigna radiata (mung dal). However, the poorer people cannot usually afford these two pulses and consume instead Lathyrus sativus (khesari dal).

3.3. Plant Habitat. Among the plants whose parts were consumed, with the exception of Artocarpus heterophyllus, Corchorus capsularis, Moringa oleifera, Musa sapientum, and Raphanus sativus, the rest of the plants were collected from the wild (fallow land, roadsides, open fields, or marshy areas). Aquatic wild edible plants included Ipomoea aquatica, Marsilea minuta, Enhydra fluctuans, Nelumbo nucifera, and Nymphaea pubescens.

\subsection{Plants, Plant Parts, and Mode of Consumption during} Famines. The various informants mentioned a total of 34 nonconventional plant species that they consumed during times of food scarcity. The plants were distributed into 26 families. Among these plants species, the parts consumed were leaves, stems, barks, fruits, seeds, flowers, tubers, and corms. The results are shown in Table 1 . Leaves formed the major plant part consumed and constituted $44.9 \%$ of the total. Leaves were followed by stems at $18.3 \%$ and fruits at 12.2\%. The results are shown in Figure 2. In other parts of the world like Niger in Africa, leaves have been reported to be primarily consumed during famines and have been shown to be excellent sources of proteins and micronutrients, particularly of plants like Amaranthus viridis and M. oleifera [23]. Notably, the leaves of these two plants were also found to be consumed by the people of the present survey areas during times of food scarcity.

Fruits were usually eaten directly in the raw state, tubers and corms in the mashed state following boiling in water, and leaves and stems taken following frying or cooking in the form of vegetables. Since the households were too poor to afford spices, essentially a little oil or a small amount of table salt was added for cooking and making the dish more palatable. The three exceptions to this generalized mode of consumption were Centella asiatica, M. minuta, and Oxalis corniculata. In all these three cases, juice obtained from squeezed leaves was added to lentil soup, which was then consumed. The reason for this unusual mode of consumption was attributed to age-old practices of the community. Among these plants, not all plant parts consumed were fully nonconventional. For instance, during regular times of food availability, villagers would consume leaves and stems of Amaranthus tricolor, seeds of A. heterophyllus, leaves of C. asiatica, leaves, stems, and tubers of Colocasia esculenta, leaves of C. capsularis, leaves of I. aquatica, fruits of Musa paradisiaca, leaf stalks of $N$. pubescens, and leaves of $R$. sativus, but only occasionally. M. sapientum and Musa paradisiaca fruits were consumed during regular times, but during times of food scarcity, other parts of the plant along with fruits were consumed.

3.5. Food Uses of Famine Food Plants of Surveyed Areas in Other Parts of the World. It is of interest that the plants 


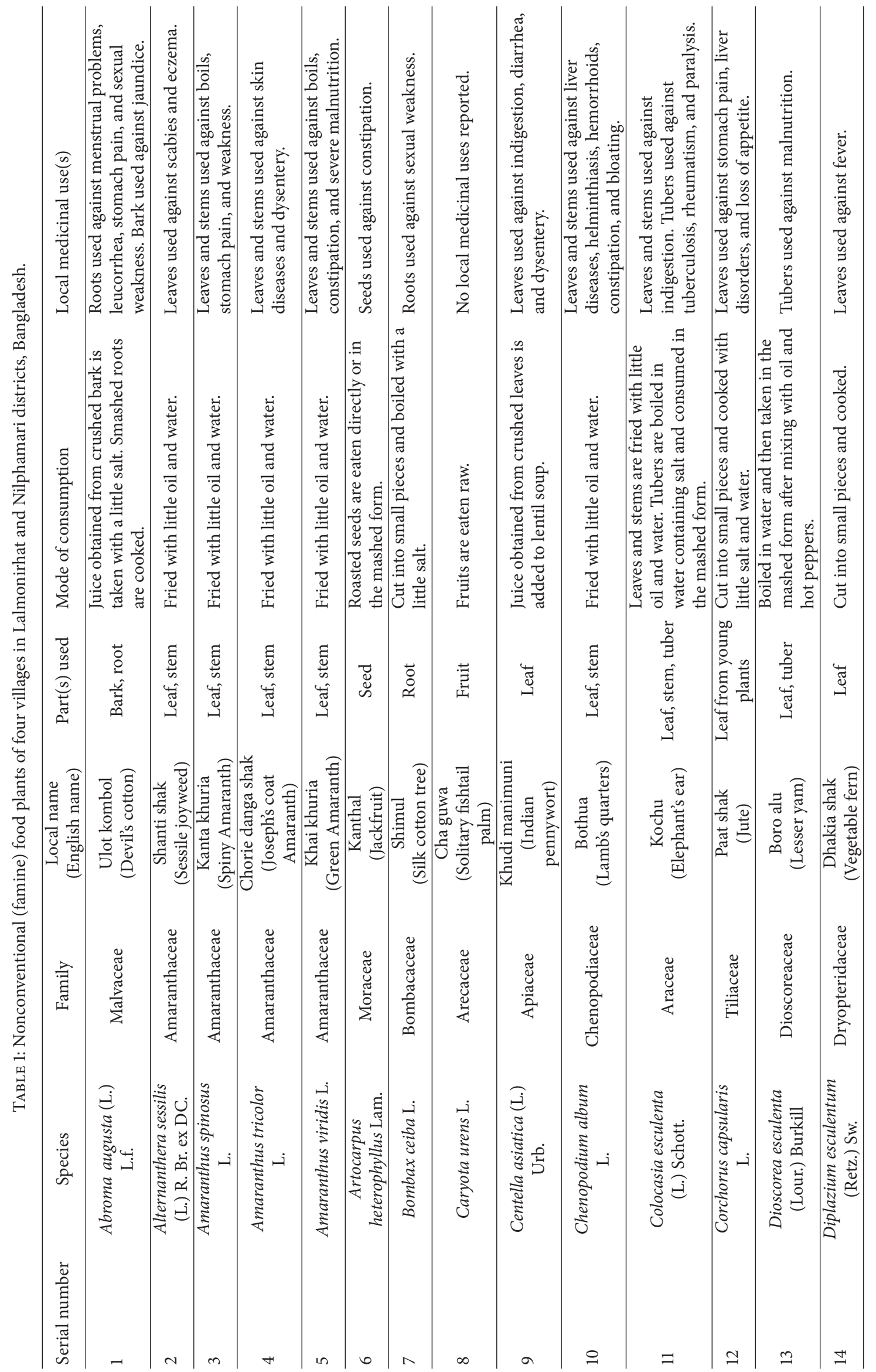




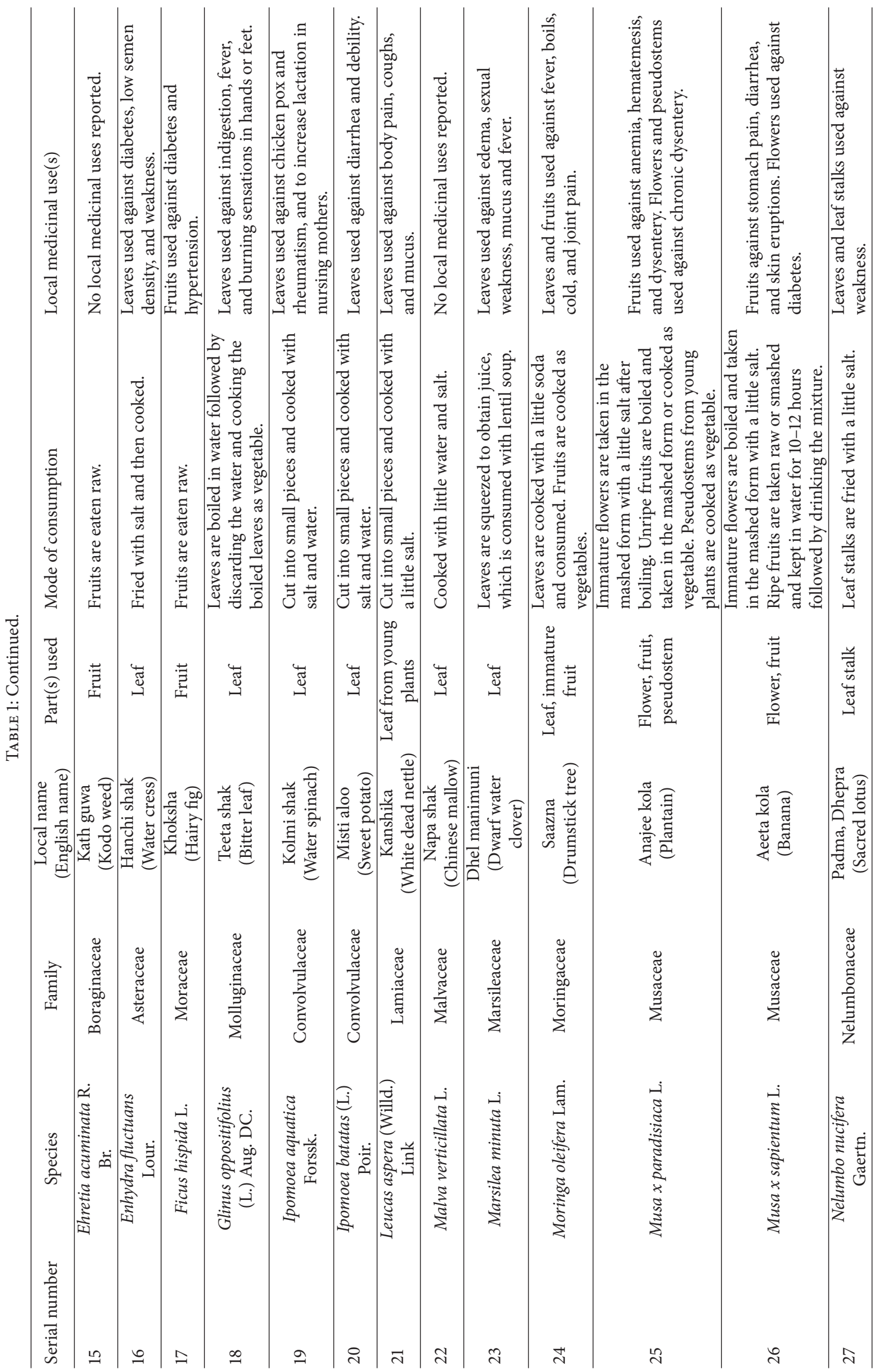




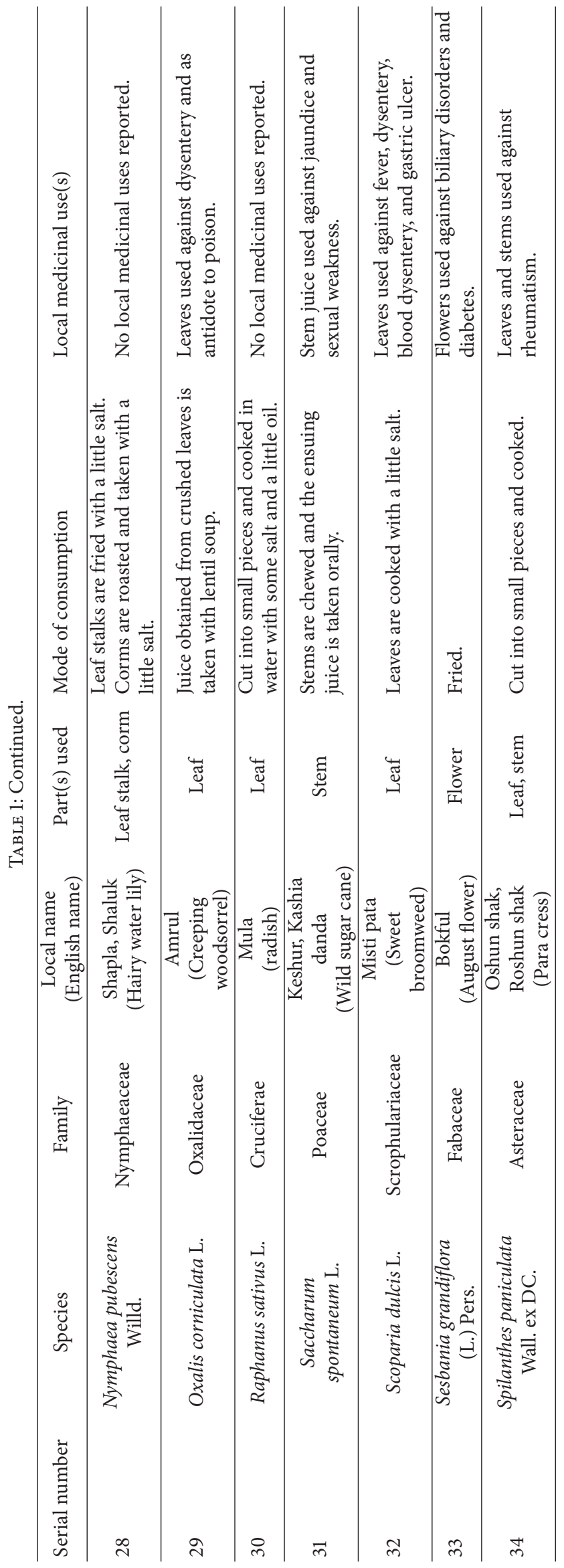




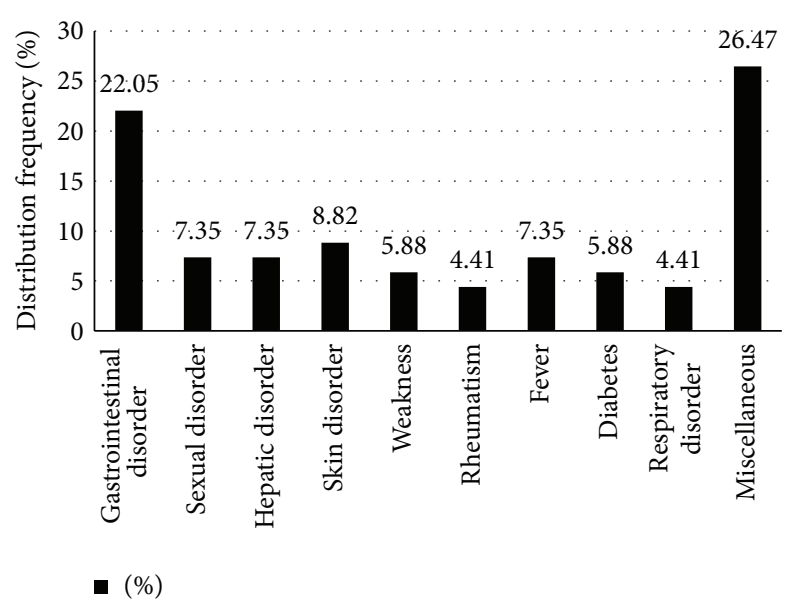

FIGURE 3: Frequency distribution (\%) of famine food plants used for treatment of various medical disorders. Besides the disorders shown in the figure, other disorders for which famine food plants were used have been classified in general as Miscellaneous.

consumed during times of food scarcity in the surveyed areas are also used as normal or famine foods in other regions of the world, although the same plant part may not be consumed. Food uses of some of the plants are shown in Table 2. For instance, leaves and seeds of Abroma augusta are considered edible in Papua New Guinea and Sikkim, India, respectively $[24,25]$. The surveyed population consumed the barks and roots of the plant. Leaves of Alternanthera sessilis are also considered edible in Papua New Guinea [24]; the surveyed population consumed leaves and stems. Leaves of Amaranthus spinosus and Amaranthus viridis are eaten as leafy vegetables in Assam, India [26]; the local people consumed both leaves and stems. The flowers of Bombax ceiba are considered edible in Arunachal Pradesh, India [27]; the local people consumed the roots of the plant.

\subsection{Local Ethnomedicinal Uses of Plants Consumed during} Famines. With the exception of five plants, the rest 29 plants ( $85.29 \%$ of total) were reported by the informants to have medicinal uses. The frequency of plant use in different categories of disorders is shown in Figure 3. Gastrointestinal disorders had the maximum frequency of ethnomedicinal use $(22.05 \%)$, followed by skin disorders $(8.82 \%)$. Other major disorders against which plants were reported to have ethnomedicinal uses included sexual disorders, hepatic disorders, and fever (7.35\% each). The rural population and particularly the surveyed rural poor households were found to live under unhygienic conditions and with poor sanitation and drinking water quality. These factors along with possible fall of immunity due to malnutrition [11] can lead to various diseases, and gastrointestinal disorders and skin diseases would constitute the major disease forms. Other studies have also indicated the prevalence of gastrointestinal disorders among the Bangladeshi rural population $[28,29]$.

3.7. Ethnomedicinal Uses of the Famine Food Plants in Other Regions of the World Including Bangladesh. To validate our hypothesis that, through trial and error, the human population has selected famine food plants items, which not only fulfill hunger satiating and nutritional needs, but also serves a therapeutic purpose, it was of interest to examine published reports on ethnomedicinal uses of the famine food plants of the survey areas in other parts of the world, including Bangladesh. The results are presented in Table 3 . It is to be noted that only a selection of available reported ethnomedicinal uses of the plants are presented in Table 3. Not surprisingly, the ethnomedicinal uses of the local famine food plants were much greater when other regions of the world were taken into account. However, some local medicinal uses were in common with uses in other regions (i.e., treatment of menstrual problems with A. augusta or use of $C$. asiatica for treatment of gastrointestinal disorders).

Taken together, the available ethnomedicinal reports on the nonconventional plants consumed by the villagers surveyed, strongly validates our hypothesis that famine food plants are also ethnomedicinal plants. That the exact ethnomedicinal value be actually known is possibly not necessary; just the mere observation that consumption of these plants satiate hunger, meet nutritional needs to a lesser or greater extent, and somehow prevents diseases from occurring can be valid reasons for selection of particular nonconventional plants and not others. For instance, the informants did not mention any medicinal uses for the plants, namely, Caryota urens, Ehretia acuminata, Malva verticillata, $N$. pubescens, and $R$. sativus (Table 1); however, all four plants have reported ethnomedicinal uses in other parts of the world (Table 3). The reasons for discarding other wild or nonconventional plants can be due to a variety of reasons ranging from toxicity and lesser palatability to lesser fulfillment of nutritional needs, with all these factors being easily manifested.

The question then arises as to why did not the villagers surveyed in the present study consume these nonconventional plant items on a regular basis? One answer provided by the villagers themselves was that they did not find these nonconventional plant items as palatable (in their words tasty) as their regular diet of rice and lentils. A further answer could be that they were unaware of all the health benefits that these nonconventional plants offered (as also suggested from a comparison of local medicinal uses of the plants versus ethnomedicinal uses in other parts of the world), and so they stuck to their millennia old dietary habits. Another possible reason could be that they once were aware of the ethnomedicinal benefits of the plants consumed but have lost some of that knowledge over time. In fact, "optimum foraging strategy" theory [30] implies that all animals forage in such a way as to maximize their net energy intake per unit time. We extend this hypothesis to include that humans forage or rather use famine food plants in such a manner which besides maximizing their net energy intake per unit time also provides them with health benefits in the form of preventing or curing diseases. This also makes sense; during malnutrition arising out of food scarcity, humans may have reduced strength and weakened body defenses; as such, they would include food, which would offer both nutritional as well as therapeutic benefits. It is interesting to note that 
TABLE 2: Reported food uses of the famine food plants.

\begin{tabular}{|c|c|}
\hline Species & Use as food plant \\
\hline Abroma augusta L. & Leaves are considered edible in Papua New Guinea [24] and seeds in Sikkim, India [25]. \\
\hline $\begin{array}{l}\text { Alternanthera sessilis (L.) } \\
\text { R. Br. ex DC. }\end{array}$ & Leaves are considered as wild edibles in Papua New Guinea [24]. \\
\hline Amaranthus spinosus L. & Consumed as leafy vegetable in Assam (India) [26]. \\
\hline Amaranthus tricolor $\mathrm{L}$. & Considered an edible vegetable in North India [34]. \\
\hline Amaranthus viridis $\mathrm{L}$. & Consumed as leafy vegetable in Assam (India) [26]. \\
\hline Artocarpus heterophyllus Lam. & Fruits and seeds consumed in Malaysia [35]. \\
\hline Bombax ceiba L. & Flowers eaten as vegetable in Arunachal Pradesh of India [27]. \\
\hline Caryota urens L. & Pith used as famine food in South India [36]. \\
\hline Centella asiatica (L.) Urb. & Considered a leafy vegetable in Assam (India) [26]. \\
\hline Chenopodium album L. & Considered a leafy vegetable in Assam (India) [26]. \\
\hline Colocasia esculenta (L.) Schott. & Considered a leafy vegetable in Assam (India) [26]. \\
\hline Corchorus capsularis L. & Leaves are eaten in the cooked form in some Asian countries [37]. \\
\hline $\begin{array}{l}\text { Dioscorea esculenta (Lour.) } \\
\text { Burkill }\end{array}$ & Tubers are reported as wild edible in the islands of Remote Oceania [38]. \\
\hline Diplazium esculentum (Retz.) Sw. & Leaves consumed in Yunnan, China [39]. \\
\hline Ehretia acuminata R. Br. & Fruits are eaten raw by aboriginals in Australia [40]. \\
\hline Enhydra fluctuans Lour. & Leaves and stems consumed as leafy vegetable by ethnic communities in Tripura, India [41]. \\
\hline Ficus hispida L. & Fruits are eaten raw in Arunachal Pradesh of India [27]. \\
\hline $\begin{array}{l}\text { Glinus oppositifolius (L.) } \\
\text { A. DC. }\end{array}$ & Young leaves and stems consumed as vegetable in West Bengal, India [42]. \\
\hline Ipomoea aquatica Forssk. & Leaves and stems are cooked and consumed in Malaysia [35]. \\
\hline Ipomoea batatas (L.) Lam. & Leaves and stems are cooked and consumed in Malaysia [35]. \\
\hline Leucas aspera (Willd.) Link & Young leaves consumed during famine in Kurigram district, Bangladesh [10]. \\
\hline Malva verticillata $\mathrm{L}$. & Young leaves consumed as soup in Korea [43]. \\
\hline Marsilea minuta L. & Leaves and stems consumed as vegetable in Jharkand, India [44]. \\
\hline Moringa oleifera Lam. & $\begin{array}{l}\text { Leaves, fruits, flowers consumed in the cooked form in many countries of South Asia and Africa } \\
\text { [45]. }\end{array}$ \\
\hline Musa paradisiaca L. & Fruits consumed in the unripe state in tropical countries [46]. \\
\hline Musa sapientum L. & Ripe fruits consumed throughout the world [47]. \\
\hline Nelumbo nucifera Gaertn. & Consumed as vegetable in various parts of India [48]. \\
\hline Nymphaea pubescens Willd. & Roasted endosperm consumed by rural communities in Assam, India [49]. \\
\hline Oxalis corniculata $\mathrm{L}$. & Consumed by tribal communities of Central India during times of food scarcity [50]. \\
\hline Raphanus sativus L. & Dietary vegetable in Asian countries, particularly China, Japan, and Korea [51]. \\
\hline Saccharum spontaneum L. & $\begin{array}{l}\text { Stems used to mitigate thirst or hunger by tribes in Parambikulam Wildlife Sanctuary, Kerala, } \\
\text { India [52]. }\end{array}$ \\
\hline Scoparia dulcis L. & Consumed as vegetable in northeastern Thailand [53]. \\
\hline Sesbania grandiflora (L.) Pers. & Flowers and buds consumed as vegetable in India [54]. \\
\hline $\begin{array}{l}\text { Spilanthes paniculata Wall. } \\
\text { ex DC. }\end{array}$ & $\begin{array}{l}\text { Special food item prepared from the plant during religious festivals by the Mising community } \\
\text { of Assam, India [55]. }\end{array}$ \\
\hline
\end{tabular}

another study in Northeast Thailand also found that half of the weedy vegetables consumed by the people are also regarded as sources of medicine [31]. That various wild plants can serve as both food and medicine has been reported from various regions of the world including Palestine and China $[32,33]$.
The major finding of this study is that, since famine food plants have the real possibility of multiple ethnomedicinal uses, such plants throughout the world merit further scientific studies to fully explore their medicinal potentials. Moreover, since famine food plants are mostly wild but edible and can grow under inclement weather conditions without 


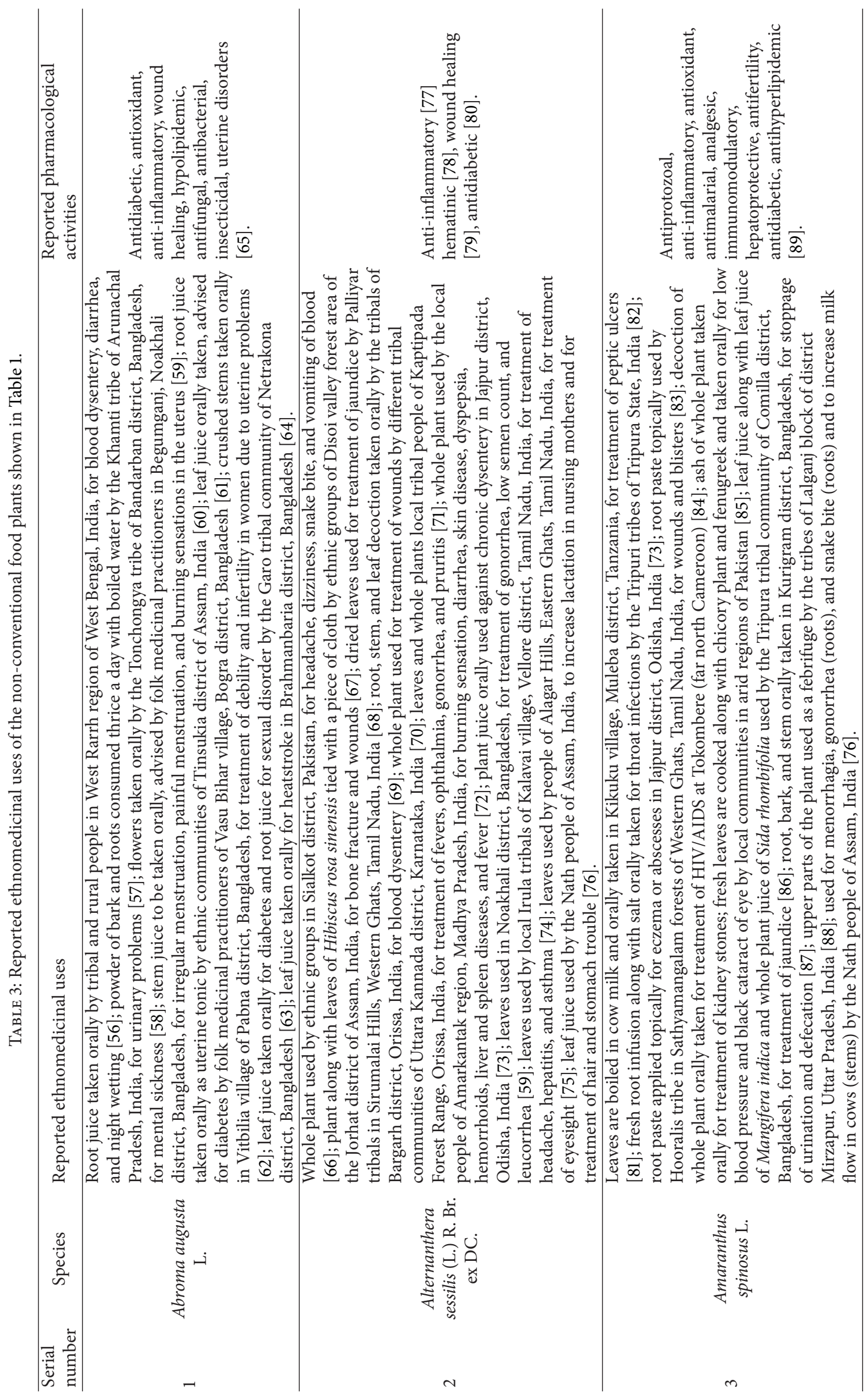




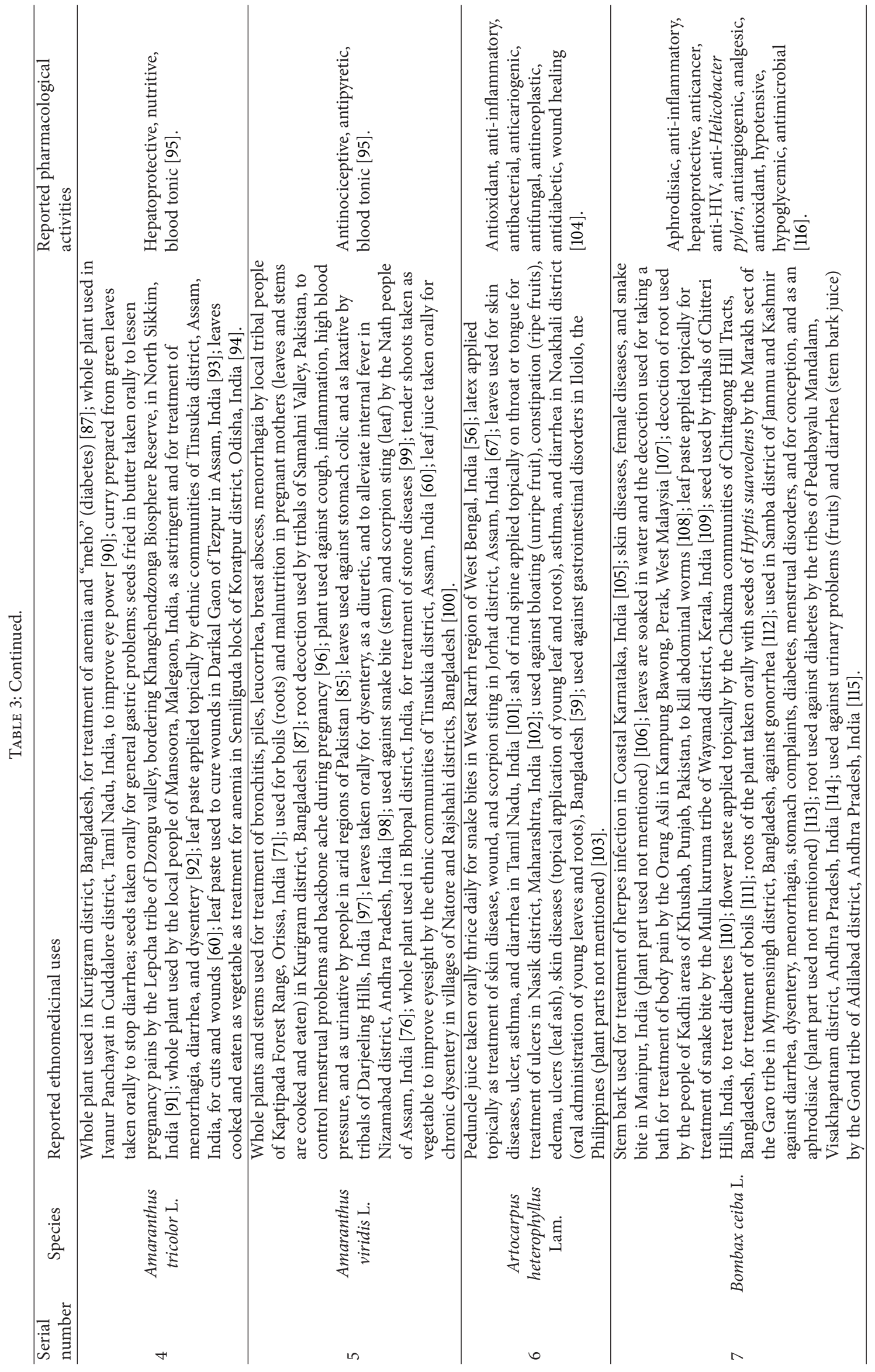




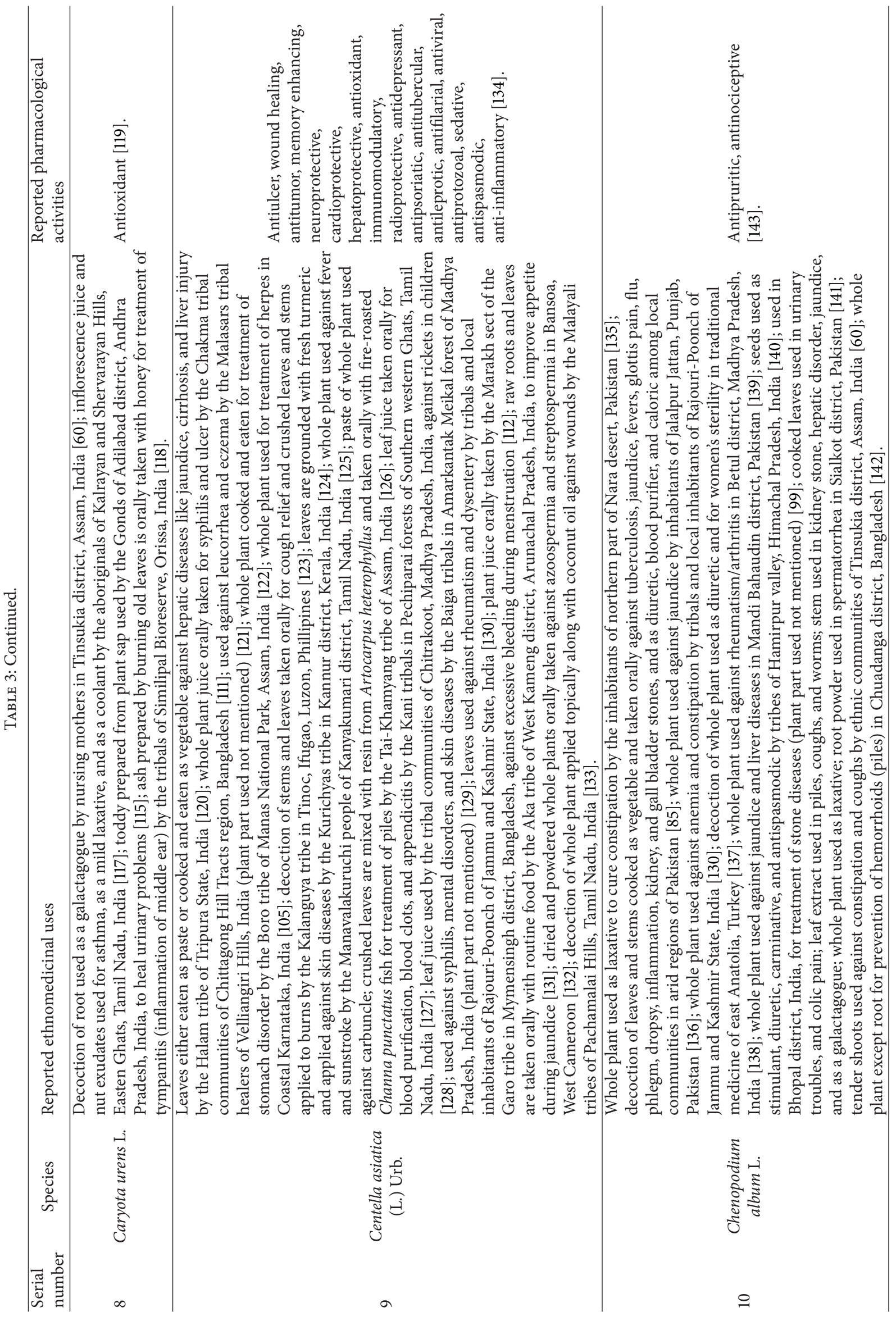




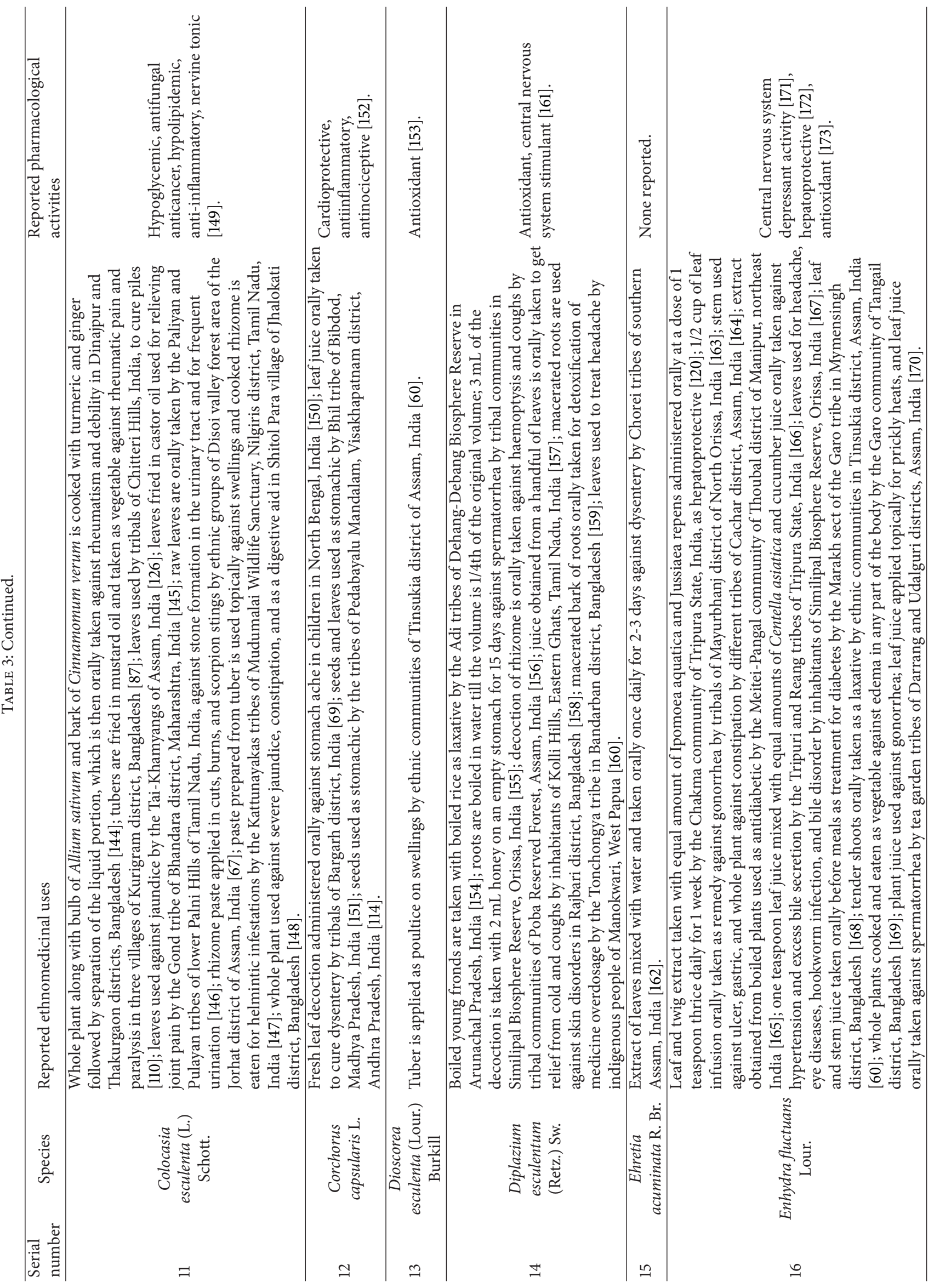




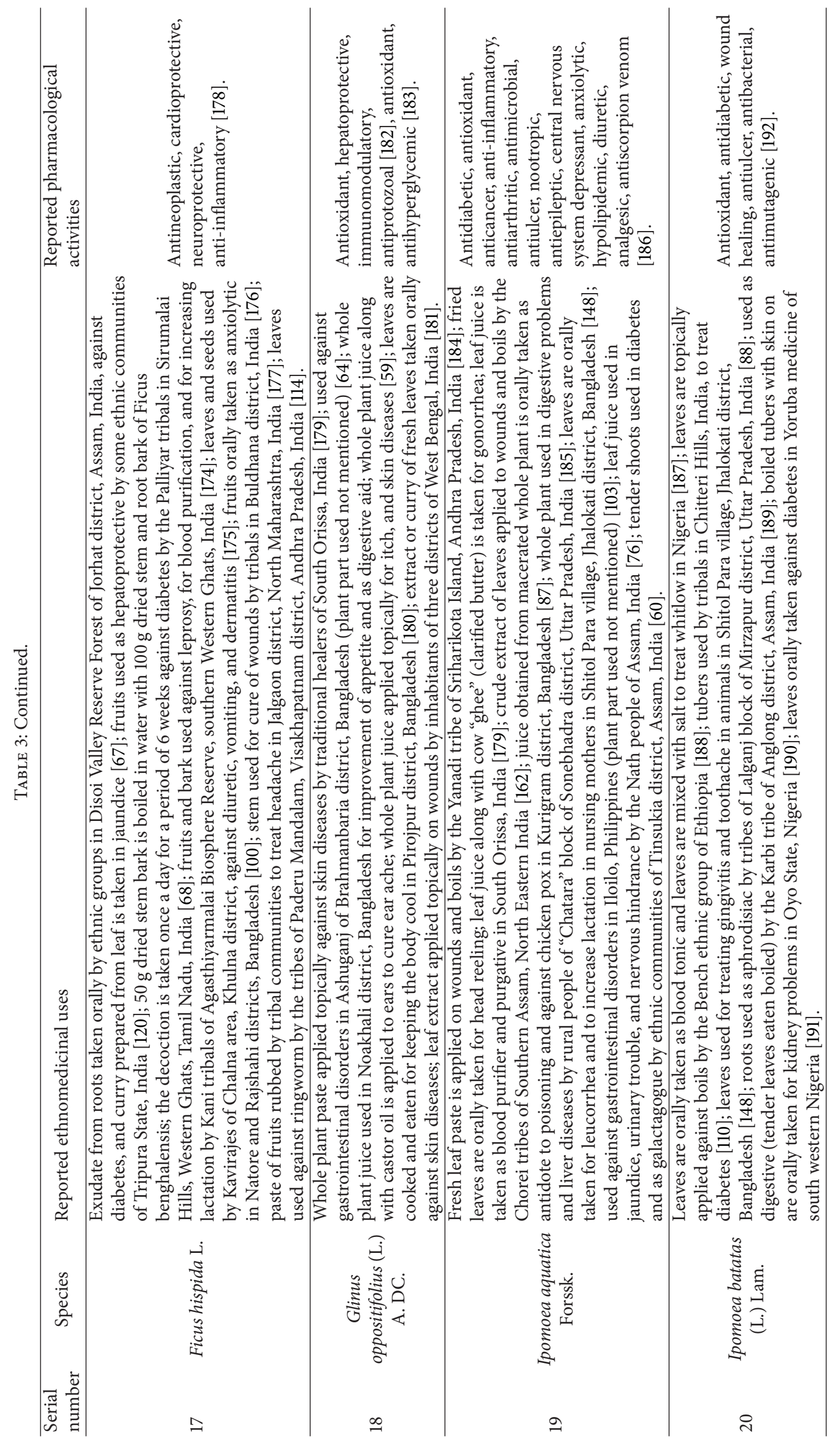




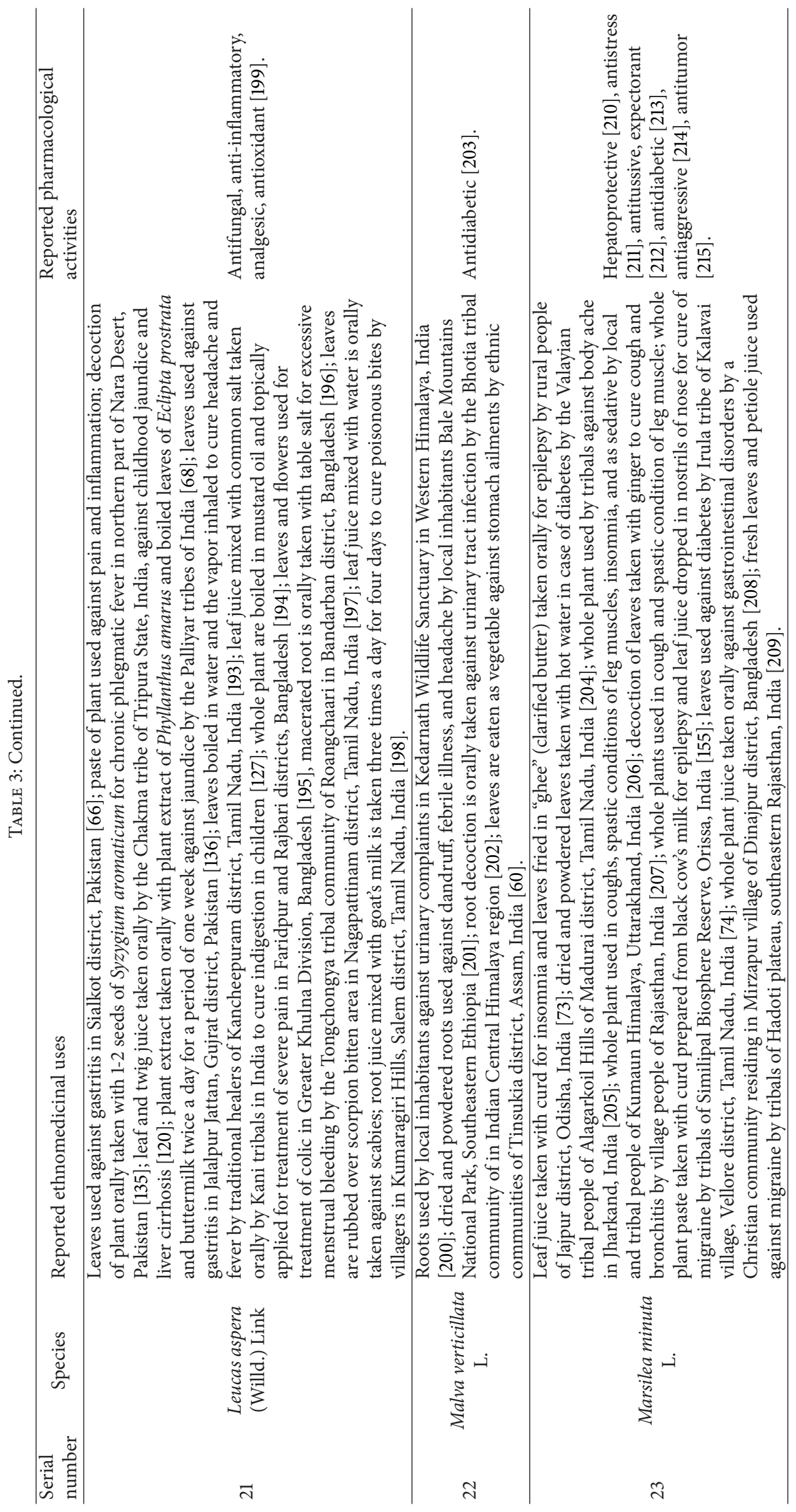




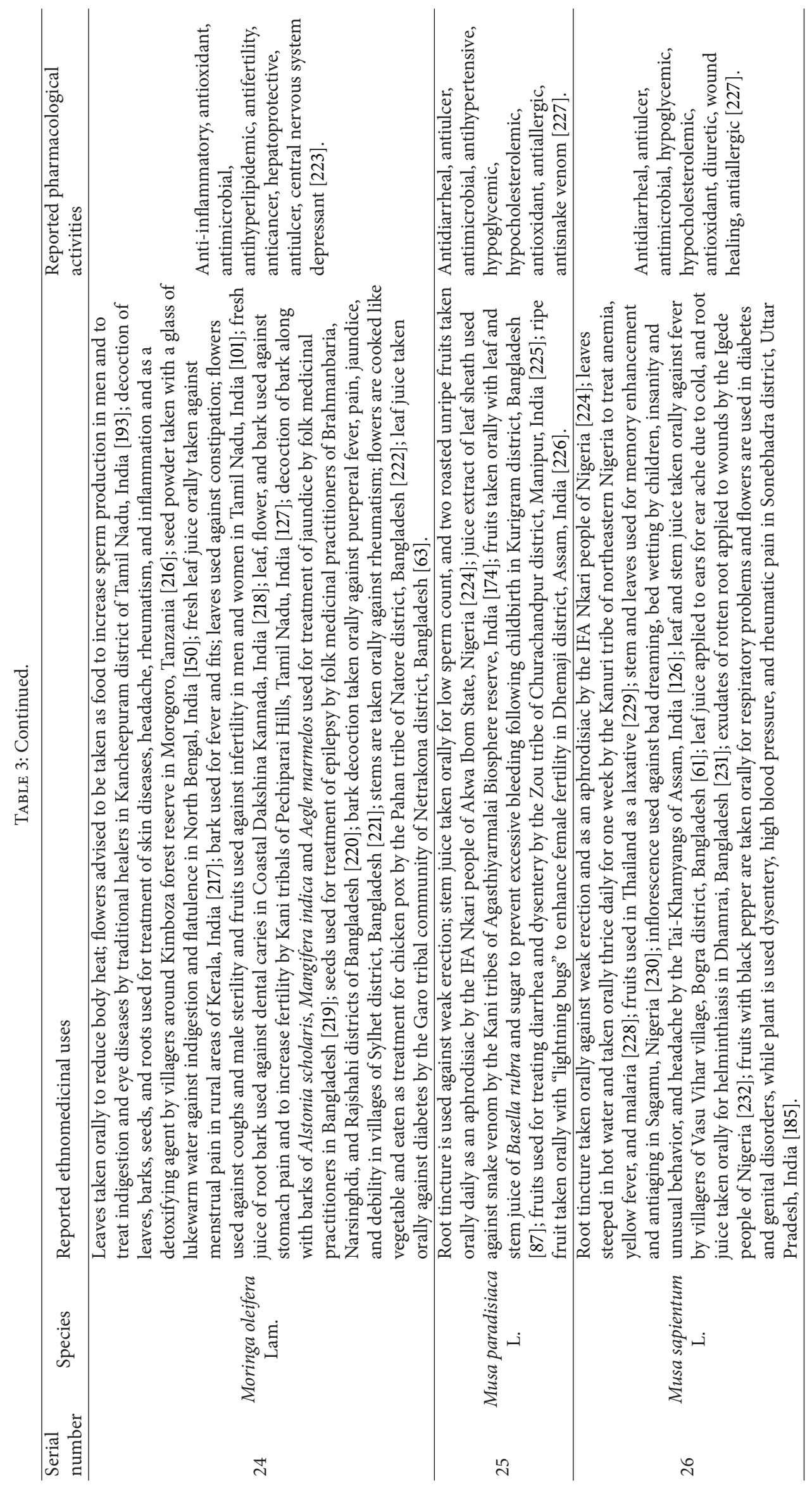




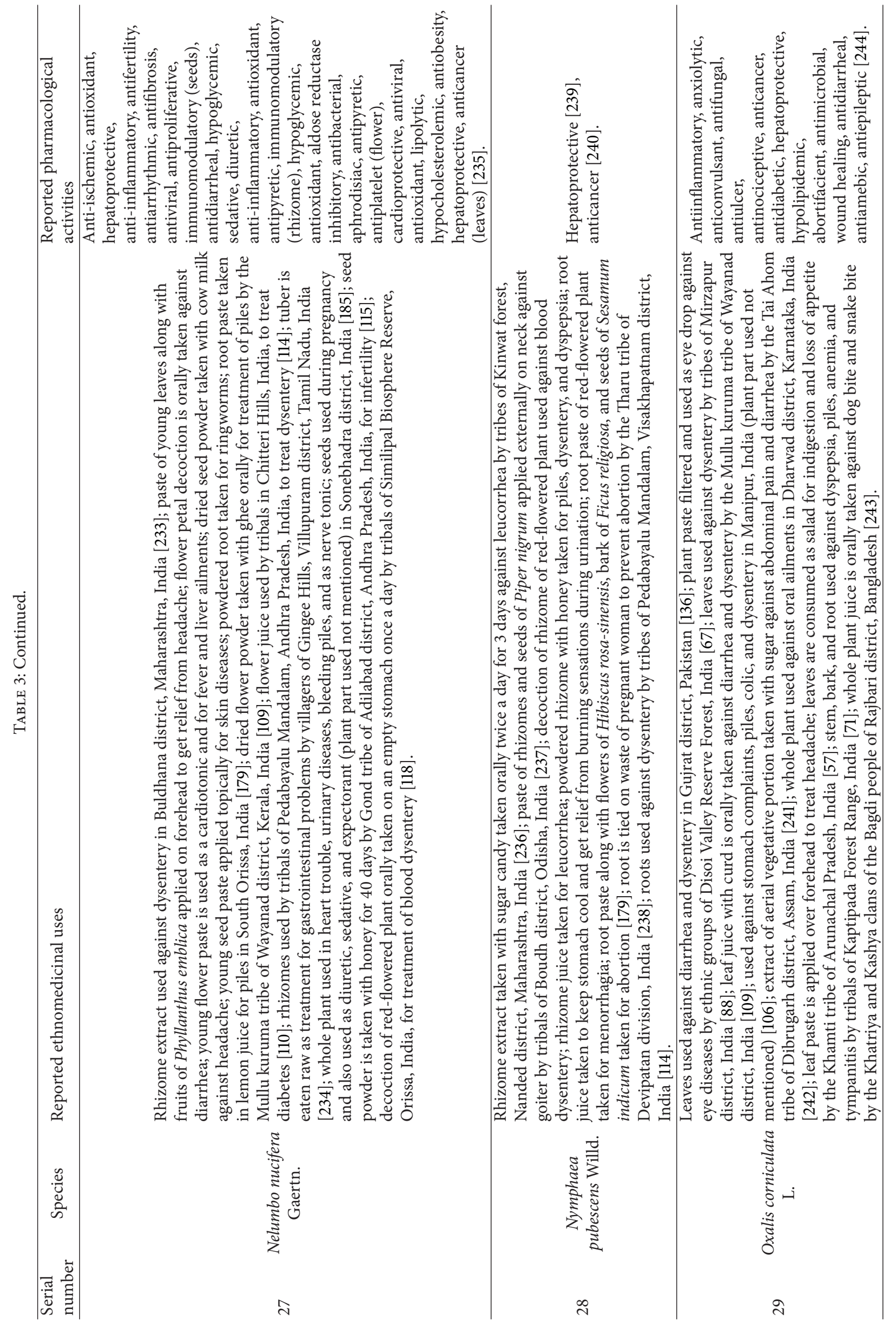




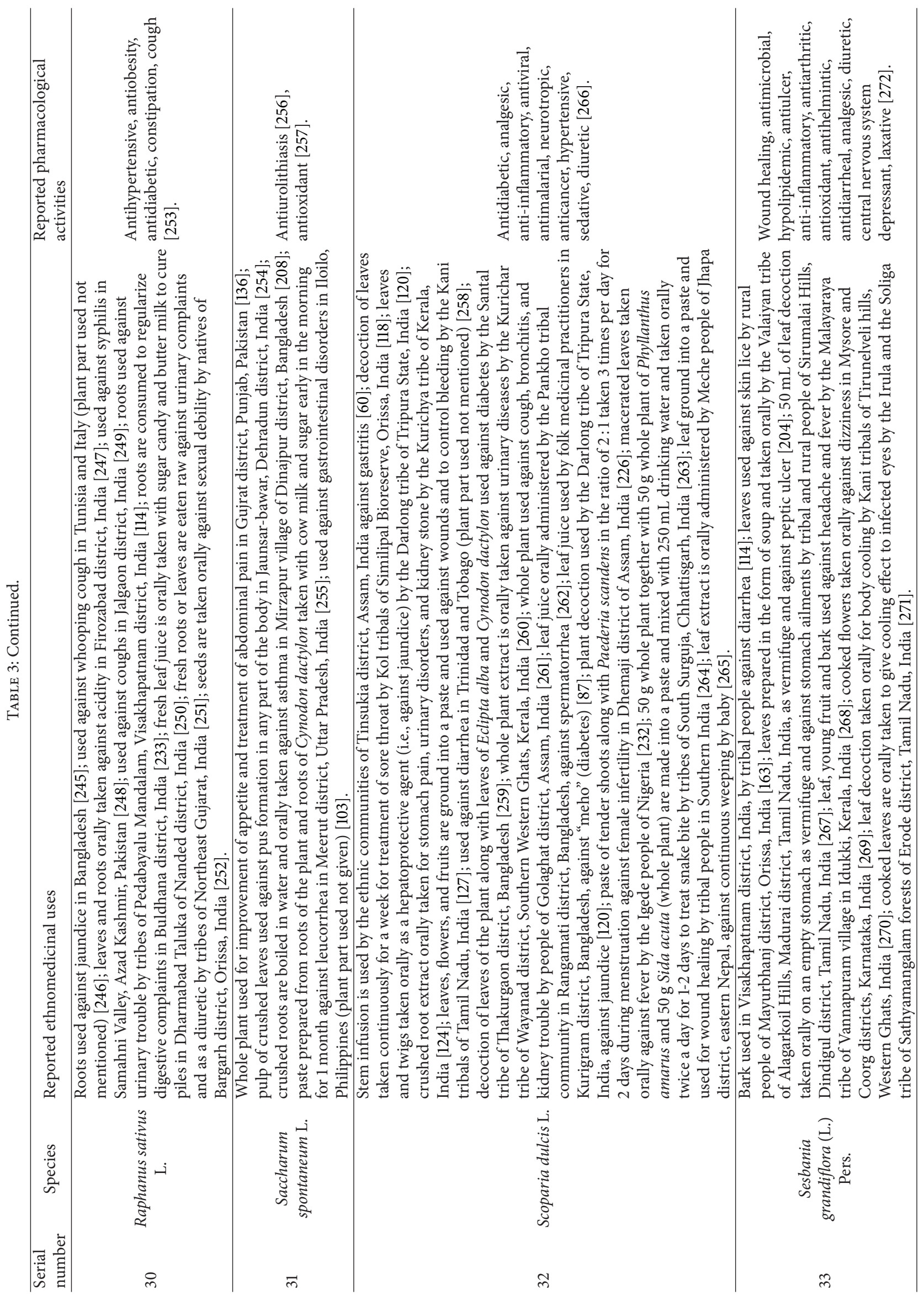




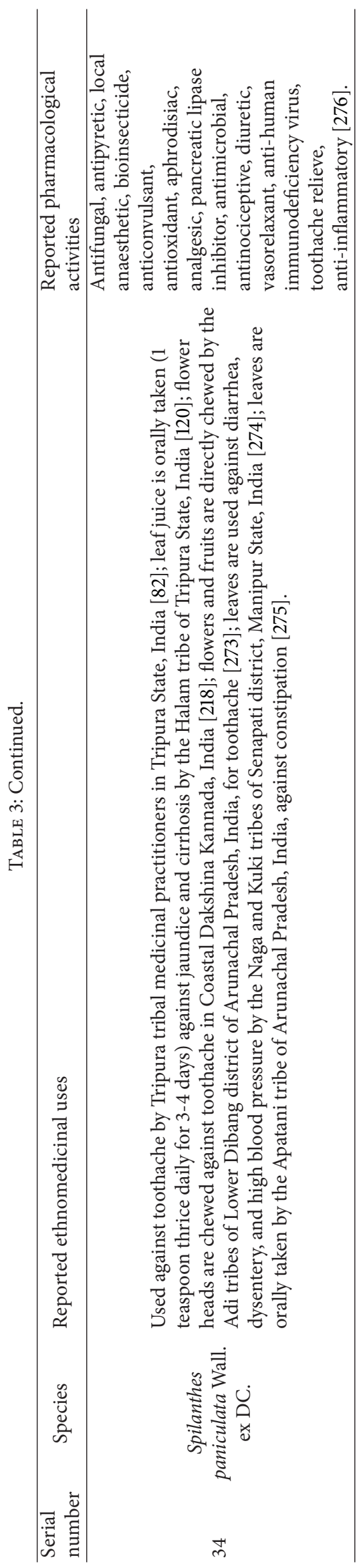


any particular care [1], they can potentially be sources of both future foods and medicine.

\section{Conclusion}

Famine food plants have generally been mentioned as unconventional dietary items and consist of wild edible plants. It was our hypothesis that such plants also serve therapeutic purposes and can be considered ethnomedicinal plants. Through local surveys among famine-affected population of two districts of Bangladesh on the unconventional plants they consume during famine periods, along with local and other reported ethnomedicinal uses on these plants, we have validated our hypothesis.

\section{Conflict of Interests}

The authors declare that they have no competing interests.

\section{Authors' Contribution}

Fardous Mohammad Safiul Azam, Anup Biswas, Abdul Mannan, Nusrat Anik Afsana, and Rownak Jahan participated and completed the survey and searched relevant ethnomedicinal literature under the supervision of Mohammed Rahmatullah and submitted an initial report of the survey. Mohammed Rahmatullah analyzed the data and wrote the paper. All authors edited the paper and read and approved the final paper.

\section{References}

[1] P. Leborgne, C. Wilkinson, S. Montembaut, and M. TesseVervers, "Scurvy outbreak in Afghanistan. An investigation by Action Contre la Faim (ACF) and the World Health Organization (WHO)," Field Exchange 17, 2002.

[2] C. Chopak, Famine Early Warning System Project, Early Warning Primer. An Overview of Monitoring and Reporting, United States Agency for International Development, 2000.

[3] R. Rodale and M. Mcgrath, "Foods that defy drought," in Save Three Lives: A Plan for Famine Prevention, R. Rodale and M. McGrath, Eds., Sierra Club Books, San Francisco, Calif, USA, 1991.

[4] Y. Guinard and D. Lemessa, Wild-Food Plants in Southern Ethiopia. Reflections on the Role of "Famine Foods" at a Time of Drought, United Nations Development Programme Emergencies Unit for Ethiopia, 2000.

[5] J. A. Cook, D. J. Vanderjagt, A. Pastuszyn et al., "Nutrient and chemical composition of 13 wild plant foods of Niger," Journal of Food Composition and Analysis, vol. 13, no. 1, pp. 83-92, 2000.

[6] S. Zug, Monga: Seasonal Food Insecurity in Bangladesh. Understanding the Problems and Strategies to Combat it. Sundarganj, Dhaka, Bochum, 2006.

[7] F. I. Jahan, M. T. Islam, M. Rajib-ul-Hasan et al., "A survey on non-conventional plant parts consumed during mongaa seasonal famine which affects the Northern Districts of Bangladesh," American-Eurasian Journal of Sustainable Agriculture, vol. 4, no. 2, pp. 230-236, 2010.

[8] A. K. Paul, P. Chakma, N. Nahar et al., "A survey of nonconventional plant items consumed during times of food scarcity by the Chakma people of Hatimara village of Rangamati district, Bangladesh," American-Eurasian Journal of Sustainable Agriculture, vol. 5, no. 1, pp. 87-91, 2011.

[9] M. T. Islam, P. R. Das, A. F. M. S. B. Mahmud et al., "A survey of non-conventional plant items consumed during food scarcity in two randomly selected villages of Kurigram district, Bangladesh," American-Eurasian Journal of Sustainable Agriculture, vol. 5, no. 2, pp. 233-239, 2011.

[10] M. Rahmatullah, F. I. Jahan, S. Seraj et al., "Correlation between non-conventional plants consumed during food scarcity and their folk medicinal usages: a case study in two villages of Kurigram district, Bangladesh," American-Eurasian Journal of Sustainable Agriculture, vol. 5, no. 2, pp. 240-246, 2011.

[11] R. K. Chandra, "Nutrition and the immune system: an introduction," The American Journal of Clinical Nutrition, vol. 66, pp. 4605-4635, 1997.

[12] J. C. Brand-Miller and S. H. A. Holt, "Australian Aboriginal plant foods: a consideration of their nutritional composition and health implications," Nutrition Research Reviews, vol. 11, no. 1, pp. 5-23, 1998.

[13] A. Fleuret, "Dietary and therapeutic uses of fruit in three Taita communities," in Plants in Indigenous Medicine and Diet, N. Etkin, Ed., pp. 151-170, Redgrave, Bedford Hills, NY, USA, 1993.

[14] G. Moreno-Black, P. Somnasang, and S. Thamathawan, "Cultivating continuity and creating change: women's home garden practices in Northeastern Thailand," Agriculture and Human Values, vol. 13, no. 3, pp. 3-11, 1996.

[15] J. Chen, "Regulatory control of functional food in China," Scandinavian Journal of Nutrition, vol. 44, no. 3, pp. 130-131, 2000.

[16] W. Weng and J. Chen, "The Eastern perspective on functional foods based on traditional Chinese medicine," Nutrition Reviews, vol. 54, pp. S11-S16, 1996.

[17] N. L. Etkin and P. J. Ross, "Food as medicine and medicine as food. An adaptive framework for the interpretation of plant utilization among the Hausa of northern Nigeria," Social Science and Medicine, vol. 16, no. 17, pp. 1559-1573, 1982.

[18] N. L. Etkin and P. J. Ross, "Should we set a place for diet in ethnopharmacology?" Journal of Ethnopharmacology, vol. 32, no. 1-3, pp. 25-36, 1991.

[19] http://www.lalmonirhat.gov.bd/, http://www.nilphamari.gov .bd/.

[20] G. J. Martin, Ethnobotany: A "People and Plants" Conservation Manual, Chapman and Hall, London, UK, 1995.

[21] P. Maundu, "Methodology for collecting and sharing indigenous knowledge: a case study," Indigenous Knowledge and Development Monitor, vol. 3, pp. 3-5, 1995.

[22] S. Bhattarai and R. P. Chaudhary, "Wild edible plants used by the people of manang district, central Nepal," Ecology of Food and Nutrition, vol. 48, no. 1, pp. 1-20, 2009.

[23] L. P. Sena, D. J. Vanderjagt, C. Rivera et al., "Analysis of nutritional components of eight famine foods of the Republic of Niger," Plant Foods for Human Nutrition, vol. 52, no. 1, pp. 17-30, 1998.

[24] B. R. French, Food Composition Tables for Food Plants in Papua New Guinea, Food Plants International, Burnie, Tasmania, 2006.

[25] M. Sundriyal, R. C. Sundriyal, and E. Sharma, "Dietary use of wild plant resources in the Sikkim Himalaya, India," Economic Botany, vol. 58, no. 4, pp. 626-638, 2004. 
[26] S. Borah, A. M. Baruah, A. K. Das, and J. Borah, "Determination of mineral content in commonly consumed leafy vegetables," Food Analytical Methods, vol. 2, no. 3, pp. 226-230, 2009.

[27] A. Angami, P. R. Gajurel, P. Rethy, B. Singh, and S. K. Kalita, "Status and potential of wild edible plants of Arunachal Pradesh," Indian Journal of Traditional Knowledge, vol. 5, pp. 541-550, 2006.

[28] A. K. Siddique, S. Ahmed, A. Iqbal et al., "Epidemiology of rotavirus and cholera in children aged less than five years in rural Bangladesh," Journal of Health, Population and Nutrition, vol. 29, no. 1, pp. 1-8, 2011.

[29] R. Haque, D. Mondal, A. Karim et al., "Prospective case-control study of the association between common enteric protozoal parasites and diarrhea in Bangladesh," Clinical Infectious Diseases, vol. 48, no. 9, pp. 1191-1197, 2009.

[30] G. H. Pyke, "Optimal foraging theory: a critical review," Annual Review of Ecology and Systematics, vol. 15, pp. 523-575, 1984.

[31] G. S. Cruz-Garcia and L. L. Price, "Weeds as important vegetables for farmers," Acta Societatis Botanicorum Poloniae, vol. 81, pp. 397-403, 2012.

[32] M. S. Ali-Shtayeh, R. M. Jamous, J. H. Al-Shafie' et al., “Traditional knowledge of wild edible plants used in Palestine (Northern West Bank): a comparative study," Journal of Ethnobiology and Ethnomedicine, vol. 4, pp. 13-25, 2008.

[33] W. Wujisguleng and K. Khasbagen, "An integrated assessment of wild vegetable resources in Inner Mongolian Autonomous Region, China," Journal of Ethnobiology and Ethnomedicine, vol. 6, pp. 34-41, 2010.

[34] S. Shukla, A. Bhargava, A. Chatterjee, J. Srivastava, N. Singh, and S. P. Singh, "Mineral profile and variability in vegetable amaranth (Amaranthus tricolor)," Plant Foods for Human Nutrition, vol. 61, no. 1, pp. 23-28, 2006.

[35] H. C. Ong, P. F. J. Mojiun, and P. Milow, “Traditional knowledge of edible plants among the Temuan villagers in Kampung Guntor, Negeri Sembilan, Malaysia," African Journal of Agricultural Research, vol. 6, no. 8, pp. 1962-1965, 2011.

[36] P. Rajyalakshmi, "Caryota palm sago: a potential yet underutilized natural resource for modern starch industry," Natural Product Radiance, vol. 3, pp. 144-149, 2004.

[37] http://www.pfaf.org/user/Plant.aspx?LatinName=Corchorus+ capsularis.

[38] W. C. McClatchey, "Wild food plants of Remote Oceania," Acta Societatis Botanicorum Poloniae, vol. 81, pp. 371-380, 2012.

[39] A. Ghorbani, G. Langenberger, and J. Sauerborn, "A comparison of the wild food plant use knowledge of ethnic minorities in Naban River Watershed National Nature Reserve, Yunnan, SW China," Journal of Ethnobiology and Ethnomedicine, vol. 8, pp. $17-25,2012$

[40] http://www.pfaf.org/user/Plant.aspx?LatinName=Ehretia+acuminata.

[41] D. Deb, A. Sarkar, B. D. Barma, B. K. Datta, and K. Majumdar, "Wild edible plants and their utilization in traditional recipes of Tripura, Northeast India," Advanced Biological Research, vol. 7, pp. 203-211, 2013.

[42] S. C. Datta and A. K. Banerjee, "Useful weeds of West Bengal rice fields," Economic Botany, vol. 32, no. 3, pp. 297-310, 1978.

[43] M. Song, H. Kim, H. Brian, K. H. Choi, and B. Lee, "Traditional knowledge of wild edible plants on Jeju Island, Korea," Indian Journal of Traditional Knowledge, vol. 12, pp. 177-194, 2013.

[44] P. Soni and L. Singh, "Marsilea quadrifolia Linn.: a valuable culinary and remedial fern in Jaduguda, Jharkhand, India,"
International Journal of Life science and Pharma Research, vol. 2, pp. L99-L104, 2012.

[45] F. Anwar, S. Latif, M. Ashraf, and A. H. Gilani, "Moringa oleifera: a food plant with multiple medicinal uses," Phytotherapy Research, vol. 21, no. 1, pp. 17-25, 2007.

[46] S. A. Shodehinde and G. Oboh, "Distribution and antioxidant activity of polyphenols in boiled unripe plantain (Musa paradisiaca) pulps," Journal of Food Biochemistry, 2013.

[47] D. Mohapatra, S. Mishra, and N. Sutar, "Banana and its byproduct utilisation: an overview," Journal of Scientific and Industrial Research, vol. 69, no. 5, pp. 323-329, 2010.

[48] R. N. Mandal and R. Bar, "The sacred lotus: an increadible wealth of wetlands," Resonance, vol. 18, no. 8, pp. 732-737, 2013.

[49] D. K. Roy, A. D. Talukdar, M. D. Choudhury, and B. K. Sinha, "Less known uses of Nymphaea species (Nymphaeaceae) as the traditional food item (Vhet-laddu) in Northeast India," International Journal of Food, Agriculture and Veterinary Sciences, vol. 3, pp. 82-87, 2013.

[50] A. K. Jain, P. Tiwari, and M. Bashir, "Nutritive aspects of Oxalis corniculata L. used by tribals of Central India during scarcity of food," Botany Research International, vol. 3, pp. 35-37, 2010.

[51] S. J. Kim, M. R. Uddin, and S. U. Park, "Glucosinolate accumulation in three important radish (Raphanus sativus) cultivars," Australian Journal of Crop Science, vol. 7, pp. 1843-1847, 2013.

[52] K. Yesodharan and K. A. Sujana, "Wild edible plants traditionally used by the tribes in the Parainbikulam Wildlife Sanctuary, Kerala, India," Natural Product Radiance, vol. 6, no. 1, pp. 74-80, 2007.

[53] S. Patnibul, S. Puangmalai, A. Moung-on, and S. Sriprang, "Screening for antioxidant activity in eighteen vegetables using silica-gel thin layer chromatography followed by spraying with DPPH," NU Science Journal, vol. 5, pp. 1-6, 2008.

[54] N. Loganayaki, N. Suganya, and S. Manian, "Evaluation of edible flowers of Agathi (Sesbania grandiflora L. Fabaceae) for in vivo anti-inflammatory and analgesic, and in vitro antioxidant potential," Food Sci Biotechnol, vol. 21, pp. 509-517, 2012.

[55] U. K. Sharma and S. Pegu, "Ethnobotany of religious and supernatural beliefs of the Mising tribes of Assam with special reference to the 'Dobur Uie," Journal of Ethnobiology and Ethnomedicine, vol. 7, pp. 16-28, 2011.

[56] A. Ghosh, "Ethnomedicinal plants used in West Rarrh region of West Bengal," Natural Product Radiance, vol. 7, no. 5, pp. 461465, 2008.

[57] A. K. Das and H. Tag, "Ethnomedicinal studies of the Khamti tribe of Arunachal Pradesh," Indian Journal of Traditional Knowledge, vol. 5, pp. 317-322, 2006.

[58] M. S. Hossan, P. Roy, S. Seraj et al., "Ethnomedicinal knowledge among the Tongchongya tribal community of Roangchaari Upazila of Bandarban district, Bangladesh," American-Eurasian Journal of Sustainable Agriculture, vol. 6, pp. 349-359, 2012.

[59] M. Rahmatullah, A. A. Mahmud, M. A. Rahman et al., "An ethnomedicinal survey conducted amongst folk medicinal practitioners in the two southern districts of Noakhali and Feni, Bangladesh," American-Eurasian Journal of Sustainable Agriculture, vol. 5, no. 1, pp. 115-131, 2011.

[60] J. Buragohain, "Ethnomedicinal plants used by the ethnic communities of Tinsukia district of Assam, India," Recent Research in Science and Technology, vol. 3, pp. 31-42, 2011.

[61] M. Rahmatullah, M. R. Islam, M. Z. Kabir et al., "Folk medicinal practices in Vasu Bihar village, Bogra district, Bangladesh," American-Eurasian Journal of Sustainable Agriculture, vol. 4, no. 1, pp. 86-93, 2010. 
[62] M. Rahmatullah, M. A. H. Mollik, M. Ali et al., "An ethnomedicinal survey of vitbilia village in sujanagar sub-district of pabna district, Bangladesh," American-Eurasian Journal of Sustainable Agriculture, vol. 4, no. 3, pp. 302-308, 2010.

[63] M. Rahmatullah, I. J. Mukti, A. K. M. F. Haque et al., "An ethnobotanical survey and pharmacological evaluation of medicinal plants used by the Garo tribal community living in Netrakona district, Bangladesh," Advances in Natural and Applied Sciences, vol. 3, pp. 402-418, 2009.

[64] M. A. H. Mollik, M. S. H. Hossan, A. K. Paul, M. TaufiqUr-Rahman, R. Jahan, and M. Rahmatullah, "A comparative analysis of medicinal plants used by folk medicinal healers in three districts of Bangladesh and inquiry as to mode of selection of medicinal plants," Ethnobotany Research and Applications, vol. 8, pp. 195-218, 2010.

[65] B. Gupta, S. Nayak, and S. Solanki, "Abroma augusta Linn f: a review," Der Pharmacia Sinica, vol. 2, pp. 253-261, 2011.

[66] M. Arshad, M. F. Nisar, A. Majeed, S. Ismail, and M. Ahmad, "Ethnomedicinal flora in district Sialkot, Punjab, Pakistan," Middle East Journal of Scientific Research, vol. 9, pp. 209-214, 2011.

[67] S. M. Borah, L. Borah, and S. C. Nath, "Ethnomedicinal plants from Disoi Valley Reserve Forest of Jorhat district, Assam," Plant Sciences Feed, vol. 2, pp. 59-63, 2012.

[68] A. Maruthupandian, V. R. Mohan, and R. Kottaimuthu, "Ethnomedicinal plants used for the treatment of diabetes and jaundice by Palliyar tribals in sirumalai hills, Western Ghats, Tamil Nadu, India," Indian Journal of Natural Products and Resources, vol. 2, no. 4, pp. 493-497, 2011.

[69] S. K. Sen and L. M. Behera, "Ethnomedicinal plants used by the tribals of Bargarh district to cure diarrhoea and dysentery," Indian Journal of Traditional Knowledge, vol. 7, pp. 425-428, 2008.

[70] P. Bhat, G. Hegde, and G. R. Hegde, "Ethnomedicinal practices in different communities of Uttara Kannada district of Karnataka for treatment of wounds," Journal of Ethnopharmacology, vol. 143, pp. 501-514, 2012.

[71] K. K. Behera, "Potential ethnomedicinal plants at Kaptipada Forest Range Orissa, India and their uses," Journal of Economic and Taxonomic Botany, vol. 32, supplement, pp. 194-202, 2008.

[72] A. Srivastava, S. P. Patel, R. K. Mishra, R. K. Vashistha, A. Singh, and A. K. Puskar, "Ethnomedicinal importance of the plants of Amarkantak region, Madhya Pradesh, India," International Journal of Medicinal and Aromatic Plants, vol. 2, pp. 53-59, 2012.

[73] K. B. Satapathy, B. B. Sahu, and G. S. Jena, "Crop weeds diversity and their ethnomedicinal uses in the treatment of common ailments in Jajpur district of Odisha, India," International Journal of Medicinal and Aromatic Plants, vol. 2, pp. 80-89, 2012.

[74] A. Natarajan, K. S. Leelavinodh, A. Jayavelu, K. Devi, and B. S. Kumar, "A study on ethnomedicinal plants of Kalavai, Vellore district, Tamil Nadu, India," Journal of Applied Pharmaceutical Science, vol. 3, pp. 99-102, 2013.

[75] P. Palaniappan, M. Pandian, S. Natarajan, and C. Pitchairamu, "Ethnomedicinal wisdom of Alagar Hills in Eastern Ghats, Tamil Nadu, India," International Journal of Applied Bioresearch, vol. 6, pp. 28-34, 2012.

[76] M. Sikdar and U. Dutta, "Traditional phytotherapy among the Nath people of Assam," Ethno-Medicine, vol. 2, pp. 39-45, 2008.

[77] T. Subhashini, V. Krishnaveni, and C. S. Reddy, "Anti-inflammatory activity of leaf extracts of Alternanthera sessilis," Hygeia, vol. 2, pp. 54-56, 2010.
[78] E. C. Arollado and M. O. Osi, "Hematinic activity of Alternanthera sessilis (L.) R.BR. (Amaranthaceae) in mice and rats," EInternational Scientific Research Journal, vol. 2, pp. 110-117, 2010.

[79] D. Kumarasamyraja, N. S. Jeganathan, and R. Manavalan, "A review on medicinal plants with potential wound healing activity," International Journal of Pharmaceutical Sciences, vol. 2, pp. 105-111, 2012.

[80] A. Boddupalli, R. Kumanan, A. Elumalai, M. C. Eswaraiah, N. Veldi, and N. Pendem, "A twelve-monthly review on antidiabetic plants: Jan-Dec-2011," International Research Journal of Pharmacy, vol. 3, pp. 77-80, 2012.

[81] M. J. Moshi, D. F. Otieno, and A. Weisheit, "Ethnomedicine of the Kagera Region, north western Tanzania. Part 3: plants used in traditional medicine in Kikuku village, Muleba District," Journal of Ethnobiology and Ethnomedicine, vol. 8, pp. 14-24, 2012.

[82] K. Majumdar and B. K. Datta, "A study on ethnomedicinal usage of plants among the folklore herbalists and Tripuri medical practitioners: part-II," Natural Product Radiance, vol. 6, no. 1, pp. 66-73, 2007.

[83] P. Revathi, T. Parimelazhagan, and S. Manian, "Ethnomedicinal plants and novel formulations used by Hooralis tribe in Sathyamangalam forests, Western Ghats of Tamil Nadu, India," Journal of Medicinal Plants Research, vol. 7, pp. 2083-2097, 2013.

[84] E. Noumi and B. Anguessin, "Insecticides and ethnomedicine of HIV/AIDS at Tokombere (Far North Cameroon)," Indian Journal of Traditional Knowledge, vol. 9, no. 4, pp. 730-735, 2010.

[85] A. Mushtaq, Z. Muhammad, K. M. Ajab, S. Shazia, S. G. Mujtaba, and G. Jan, "Ethnomedicinal investigation of phytomedicines among the local communities of arid regions of Pakistan," Indian Journal of Traditional Knowledge, vol. 11, pp. 436-446, 2012.

[86] H. Goswami, M. R. Hassan, H. Rahman et al., "Ethnomedicinal wisdom of the Tripura tribe of Comilla district, Bangladesh: a combination of medicinal plant knowledge and folk beliefs," American-Eurasian Journal of Sustainable Agriculture, vol. 7, pp. 178-187, 2013.

[87] P. R. Das, M. T. Islam, A. S. M. S. H. B. Mahmud et al., "An ethnomedicinal survey conducted among the folk medicinal practitioners of three villages in Kurigram district, Bangladesh," American-Eurasian Journal of Sustainable Agriculture, vol. 6, pp. 85-96, 2012.

[88] M. Tiwari and R. H. Singh, "Ethnomedicinal practices among the tribes of Lalganj block of district Mirzapur, Uttar Pradesh," Life Sciences Leaflets, vol. 10, pp. 84-99, 2012.

[89] D. Jhade, D. Ahirwar, R. Jain, N. K. Sharma, and S. Gupta, "A pharmacological review: Amaranthus spinosus," Research Journal of Pharmacognosy and Phytochemistry, vol. 1, pp. 169$172,2009$.

[90] S. Manikandan, "Ethnomedicinal flora of Ivanur Panchayat in Cuddalore district, Tamil Nadu, India," International Research Journal of Plant Science, vol. 3, pp. 39-46, 2013.

[91] B. K. Pradhan and H. K. Badola, "Ethnomedicinal plant use by Lepcha tribe of Dzongu valley, bordering Khangchendzonga Biosphere Reserve, in North Sikkim, India," Journal of Ethnobiology and Ethnomedicine, vol. 4, pp. 22-39, 2008.

[92] W. Ahmad, A. Hasan, I. Ahmad, and F. Zeenat, "Ethnomedicinal plants of Mansoora, Malegaon," Hamdard Medicus, vol. 54, pp. 29-40, 2011.

[93] A. J. Das, M. Athar, D. S. Rawat, and P. J. Das, "Ethno medicinal survey of medicinal plants used to cure wounds in Darikal Gaon 
of Tezpur in Assam, North East India," International Research Journal of Pharmacy, vol. 3, pp. 193-195, 2012.

[94] S. Raut, S. Raut, S. K. Sen, S. Satpathy, and D. Pattnaik, "An ethnobotanical survey of medicinal plants in Semiliguda of Koratpur district, Odisha, India," Botany Research International, vol. 5, pp. 97-107, 2012.

[95] C. K. A. Kumar, M. S. D. Sree, A. Joshna, S. M. Lakshmi, and D. S. Kumar, "A review on South Indian edible leafy vegetables," Journal of Global Trends in Pharmaceutical Sciences, vol. 4, pp. 1248-1256, 2013.

[96] I. C. Muhammad and M. A. Khan, "An ethnomedicinal inventory of plants used for family planning and sex diseases in Samahni Valley, Pakistan," Indian Journal of Traditional Knowledge, vol. 7, pp. 277-283, 2008.

[97] J. Saha, P. K. Sarkar, and S. Chattopadhyay, "A survey of ethnomedicinal plants of Darjeeling hills for their antimicrobial and antioxidant activities," Indian Journal of Natural Products and Resources, vol. 2, no. 4, pp. 479-492, 2011.

[98] P. Sudhakar and J. Shashikanth, "Ethnomedicinal importance of some weeds grown in sugarcane crop fields of Nizamabad district, Andhra Pradesh, India," Life Sciences Leaflets, vol. 10, pp. 51-55, 2012.

[99] K. Agarwal and R. Varma, "Some ethnomedicinal plants of Bhopal district used for treating stone diseases," International Journal of Pharmaceutical and Life Sciences, vol. 3, pp. 13561362, 2012.

[100] F. Mawla, S. Khatoon, F. Rehana et al., "Ethnomedicinal plants of folk medicinal practitioners in four villages of Natore and Rajshahi districts, Bangladesh," American-Eurasian Journal of Sustainable Agriculture, vol. 6, pp. 406-416, 2012.

[101] M. Gunasekaran and P. Balasubramanian, "Ethnomedicinal uses of sthalavrikshas (temple trees) in Tamil Nadu, southern India," Ethnobotany Research and Applications, vol. 10, pp. 253268, 2012.

[102] M. V. Patil and D. A. Patil, "Ethnomedicinal practices of Nasik district, Maharashtra," Indian Journal of Traditional Knowledge, vol. 4, pp. 287-290, 2005.

[103] R. G. Tantiado, "Survey on ethnopharmacology of medicinal plants in Iloilo, Philippines," International Journal of Bio-Science and Bio-Technology, vol. 4, pp. 11-26, 2012.

[104] M. S. Baliga, A. R. Shivashankara, R. Haniadka, J. Dsouza, and H. P. Bhat, "Phytochemistry, nutritional and pharmacological properties of Artocarpus heterophyllus Lam (jackfruit): a review," Food Research International, vol. 44, pp. 1800-1811, 2011.

[105] M. J. Bhandary and K. R. Chandrashekar, "Herbal therapy for herpes in the ethno-medicine of Coastal Karnataka," Indian Journal of Traditional Knowledge, vol. 10, no. 3, pp. 528-532, 2011.

[106] A. D. Khumbongmayum, M. L. Khan, and R. S. Tripathi, "Ethnomedicinal plants in the sacred groves of Manipur," Indian Journal of Traditional Knowledge, vol. 4, pp. 21-32, 2005.

[107] A. J. S. J. Samuel, A. Kalusalingam, D. K. Chellappan et al., "Ethnomedical survey of plants used by the Orang Asli in Kampung Bawong, Perak, West Malaysia," Journal of Ethnobiology and Ethnomedicine, vol. 6, pp. 5-10, 2010.

[108] R. Qureshi, M. Maqsood, M. Arshad, and A. K. Chaudhry, "Ethnomedicinal uses of plants by the people of kadhi areas of Khushab, Punjab, Pakistan," Pakistan Journal of Botany, vol. 43, no. 1, pp. 121-133, 2011.

[109] V. P. Silja, K. S. Varma, and K. V. Mohanan, "Ethnomedicinal plant knowledge of the Mullu kuruma tribe of Wayanad district, Kerala," Indian Journal of Traditional Knowledge, vol. 7, pp. 604612, 2008.
[110] K. Kadhirvel, S. Ramya, T. P. S. Sudha et al., "Ethnomedicinal survey on plants used by tribals in Chitteri Hills," International Journal of Environmental Science and Technology, vol. 5, pp. 3546, 2010.

[111] T. Khisha, R. Karim, S. R. Chowdhury, and R. Banoo, "Ethnomedical studies of Chakma communities of Chittagong Hill Tracts, Bangladesh," Bangladesh Pharmaceutical Journal, vol. 15, pp. 59-67, 2012.

[112] M. Rahmatullah, M. N. K. Azam, I. Malek et al., "An ethnomedicinal survey among the marakh sect of the Garo tribe of Mymensingh district, Bangladesh," International Journal of PharmTech Research, vol. 4, no. 1, pp. 141-149, 2012.

[113] B. L. Bhellum and S. Singh, "Ethnomedicinal plants of district Samba of Jammu and Kashmir State (List-II)," International Journal of Medical Science and Public Health, vol. 2, pp. 1-8, 2012.

[114] S. B. Padal, P. Chandrasekhar, and K. Satyavathi, "Ethnomedicinal investigation of medicinal plants used by the tribes of Pedabayalu Mandalam, Visakhapatnam district, Andhra Pradesh, India," International Journal of Computer Engineering Research, vol. 3, pp. 8-13, 2013.

[115] E. N. Murthy, "Ethno medicinal plants used by gonds of Adilabad district, Andhra Pradesh, India," International Journal of Pharmaceutical and Life Sciences, vol. 3, pp. 2034-2043, 2012.

[116] P. H. Chaudhary and S. S. Khadabadi, "Bombax ceiba Linn.: pharmacognosy, ethnobotany and phyto-pharmacology," Pharmacognosy Communications, vol. 2, pp. 2-9, 2012.

[117] K. Kadavul and A. K. Dixit, "Ethnomedicinal species of the woody species of Kalrayan and Shervarayan Hills, Eastern Ghats, Tamil Nadu," Indian Journal of Traditional Knowledge, vol. 8, pp. 592-597, 2009.

[118] K. K. Behera, "Ethnomedicinal plants used by the tribals of Similipal Bioreserve, Orissa, India: a pilot study," Ethnobotanical Leaflets, vol. 10, pp. 149-173, 2006.

[119] P. Ranasinghe, G. A. S. Premakumara, C. D. Wijayarathna, and W. D. Ratnasooriya, "Antioxidant activity of Caryota urens L., (Kithul) sap," Tropical Agricultural Research, vol. 23, pp. 117-125, 2012.

[120] S. Das, M. D. Choudhury, S. C. Mandal, and A. Talukdar, "Traditional knowledge of ethnomedicinal hepatoprotective plants used by certain ethnic communities of Tripura State," Indian Journal of Fundamental and Applied Life Sciences, vol. 2, pp. 84-97, 2012.

[121] S. Ragupathy, N. G. Steven, M. Maruthakkutti, B. Velusamy, and M. M. Ul-Huda, "Consensus of the "Malasars" traditional aboriginal knowledge of medicinal plants in the Velliangiri holy hills, India," Journal of Ethnobiology and Ethnomedicine, vol. 4, pp. 8-21, 2008.

[122] S. Das, M. L. Khan, A. Rabha, and D. K. Bhattarcharjya, "Ethnomedicinal plants of Manas National Park, Assam, Northeast India," Indian Journal of Traditional Knowledge, vol. 8, pp. 514517, 2009.

[123] T. D. Balangcod and A. K. D. Balangcod, "Ethnomedical knowledge of plants and healthcare practices among the Kalanguya tribe in Tinoc, Ifugao, Luzon, Philippines," Indian Journal of Traditional Knowledge, vol. 10, no. 2, pp. 227-238, 2011.

[124] N. P. Rajith and V. S. Ramachandran, "Ethnomedicines of Kurichyas, Kannur district, Western Ghats, Kerala," Indian Journal of Natural Products and Resources, vol. 1, no. 2, pp. 249253, 2010.

[125] A. J. D. Britto, R. M. Sujin, R. Mahesh, and K. Dharmar, "Ethnomedicinal wisdom of the Manavalakuruchi people in 
Kanyakumari district, Tamil Nadu," International Journal of Biological Technology, vol. 1, pp. 25-30, 2010.

[126] R. Sonowal and I. Barua, "Ethnomedical practices among the Tai-Khamyangs of Assam, India," Studies on Ethno-Medicine, vol. 5, no. 1, pp. 41-50, 2011.

[127] K. Subitha, M. T. Ayyanar, M. Udayakumar, and T. Sekar, "Ethnomedicinal plants used by Kani tribals in Pechiparai forests of Southern western Ghats, Tamil Nadu, India," International Research Journal of Plant Science, vol. 2, pp. 349-354, 2011.

[128] R. L. S. Sikarwar, B. Pathak, and A. Jaiswal, "Some unique ethnomedicinal perceptions of tribal communities of Chitrakoot, Madhya Pradesh," Indian Journal of Traditional Knowledge, vol. 7, pp. 613-617, 2008.

[129] R. Kapale, "Ethnomedicinal plants used by Baiga tribals in Amarkantak Meikal forest of Madhya Pradesh (India)," Bulletin of Environment, Pharmacology and Life Sciences, vol. 1, pp. 14-15, 2012.

[130] S. A. Azad and A. R. Bhat, "Ethnomedicinal plants recorded from Rajouri-Poonch districts of J \& K State," Indian Journal of Life Sciences, vol. 2, pp. 77-79, 2013.

[131] G. Nimachow, J. S. Rawat, A. Arunachalam, and O. Dai, "Ethnomedicines of Aka tribe, West Kameng district, Arunachal Pradesh (India)," Science \& Culture, vol. 77, pp. 149-155, 2011.

[132] E. Noumi, A. F. Eboule, and R. Nanfa, "Traditional health care of male infertility in Bansoa, West Cameroon," International Journal of Pharmaceutical and Biomedical Sciences, vol. 2, pp. 42-50, 2011.

[133] A. Bhaskar and L. R. Samant, "Traditional medication of Pachamalai Hills, Tamilnadu, India," Global Journal of Pharmacology, vol. 6, pp. 47-51, 2012.

[134] S. S. Jamil, Q. Nizami, and M. Salam, “Centella asiatica (Linn.) Urban-a review," Natural Product Radiance, vol. 6, no. 2, pp. 158-170, 2007.

[135] R. Qureshi, G. R. Bhatti, and R. A. Memon, "Ethnomedicinal uses of herbs from northern part of Nara desert, pakistan," Pakistan Journal of Botany, vol. 42, no. 2, pp. 839-851, 2010.

[136] K. Hussain, M. F. Nisar, A. Majeed, K. Nawaz, and K. H. Bhatti, "Ethnomedicinal survey for important plants of Jalalpur Jattan, district Gujrat, Punjab, Pakistan," Ethnobotanical Leaflets, vol. 14, pp. 807-825, 2010.

[137] E. Altundag and M. Ozturk, "Ethnomedicinal studies on the plant resources of east Anatolia, Turkey," Procedia, vol. 19, pp. 756-777, 2011.

[138] S. P. Jain, S. C. Singh, S. Srivastava, J. Singh, N. P. Mishra, and A. Prakash, "Hitherto unreported ethnomedicinal uses of plants of Betul district of Madhya Pradesh," Indian Journal of Traditional Knowledge, vol. 9, no. 3, pp. 522-525, 2010.

[139] M. F. Nisar, S. Ismail, M. Arshad, A. Majeed, and M. Arfan, "Ethnomedicinal flora of District Mandi Bahaudin, Pakistan," Middle East Journal of Scientific Research, vol. 9, pp. 233-238, 2011.

[140] S. Sharma, A. Thakur, P. Verma, S. Kumari, S. Sharma, and V. Arya, "Ethnomedicinal wisdom among local tribes in Hamirpur valley, Himachal Pradesh, India," Journal of the History of Medicine and Allied Sciences, vol. 2, pp. 88-94, 2012.

[141] A. Mahmood, A. Mahmood, and A. Tabassum, "Ethnomedicinal survey of plants from district Sialkot, Pakistan," Journal of Applied Pharmaceutical Science, vol. 2, pp. 212-220, 2011.

[142] K. R. Biswas, T. Ishika, M. Rahman et al., "Medicinal plants used for preventive medicinal purposes: a survey in Muktipara village, Chuadanga district, Bangladesh," American-Eurasian Journal of Sustainable Agriculture, vol. 5, no. 2, pp. 247-251, 2011.
[143] N. Yadav, N. Vasudeva, S. Singh, and S. K. Sharma, "Medicinal properties of genus Chenopodium Linn," Natural Product Radiance, vol. 6, no. 2, pp. 131-134, 2007.

[144] A. Rahman, J. Islam, S. Jahan et al., "Differences in selection of medicinal plants between folk and tribal medicine: a case study of a Santal tribal and a non-Santal folk medicinal practitioner in two adjoining districts of Bangladesh," American-Eurasian Journal of Sustainable Agriculture, vol. 7, pp. 85-98, 2013.

[145] R. Gupta, M. G. Vairale, R. R. Deshmukh, P. R. Chaudhary, and S. R. Wate, "Ethnomedicinal uses of some plants used by Gond tribe of Bhandara district, Maharashtra," Indian Journal of Traditional Knowledge, vol. 9, no. 4, pp. 713-717, 2010.

[146] S. Ganesan, N. Suresh, and L. Kesaven, "Ethnomedicinal survey of lower Palni Hills of Tamil Nadu," Indian Journal of Traditional Knowledge, vol. 3, pp. 299-304, 2004.

[147] P. S. Udayan, K. V. Tushar, S. George, and I. Balachandran, "Ethnomedicinal information from Kattunayakas tribes of Mudumalai Wildlife Sanctuary, Nilgiris district, Tamil Nadu," Indian Journal of Traditional Knowledge, vol. 6, pp. 574-578, 2007.

[148] M. Rahmatullah, M. Nuruzzaman, M. S. Hossan et al., "An ethnomedicinal survey of folk medicinal practitioners of Shitol Para village, Jhalokati district, Bangladesh," Advances in Natural and Applied Sciences, vol. 4, no. 1, pp. 85-92, 2010.

[149] R. Prajapati, M. Kalariya, R. Umbarkar, S. Parmar, and N. Sheth, "Colocasia esculenta: a potent indigenous plant," International Journal of Nutrition, Pharmacology, Neurological Diseases, vol. 1, pp. 90-96, 2011.

[150] S. Mitra and S. K. Mukherjee, "Ethnomedicinal usages of some wild plants of North Bengal plain for gastro-intestinal problems," Indian Journal of Traditional Knowledge, vol. 9, no. 4, pp. 705-712, 2010.

[151] D. Jadhav, "Ethnomedicinal plants used by Bhil tribe of Bibdod, Madhya Pradesh," Indian Journal of Traditional Knowledge, vol. 5, pp. 263-267, 2006.

[152] M. T. Islam, R. M. de Freitas, I. Sultana et al., "A comprehensive review of Corchorus capsularis: a source of nutrition, essential phytoconstituents and biological activities," Journal of Biomedical and Pharmaceutical Research, vol. 2, pp. 1-8, 2013.

[153] M. Murugan and V. R. Mohan, "In vitro antioxidant studies of Dioscorea esculenta (Lour). Burkill," Asian Pacific Journal of Tropical Biomedicine, vol. 2, no. 3, supplement, pp. S1620-S1624, 2012.

[154] R. Kagyung, P. R. Gajurel, P. Rethy, and B. Singh, "Ethnomedicinal plants used for gastro-intestinal diseases by Adi tribes of Dehang-Debang Biosphere Reserve in Arunachal Pradesh," Indian Journal of Traditional Knowledge, vol. 9, no. 3, pp. 496501, 2010.

[155] S. D. Rout, T. Panda, and N. Mishra, "Ethnomedicinal studies on some pteridophytes of Similipal Biosphere Reserve, Orissa, India," International Journal of Medicine and Medical Sciences, vol. 1, pp. 192-197, 2009.

[156] R. Pegu, J. Gogoi, A. K. Tamuli, and R. Teron, "Ethnobotanical study of wild edible plants in Poba Reserved Forest, Assam, India: multiple functions and implications for conservation," Research Journal of Agriculture and Forestry Sciences, vol. 1, pp. 1-10, 2013.

[157] V. Karthik, K. Raju, M. Ayyanar, K. Gowrishankar, and T. Sekar, "Ethnomedicinal uses of pteridophytes in Kolli Hills, Eastern Ghats of Tamil Nadu, India," Journal of Natural Product and Plant Resources, vol. 1, pp. 50-55, 2011. 
[158] R. Afroz, N. Islam, K. R. Biswas et al., "Medicinal plants used by folk medicinal practitioners in three randomly surveyed villages of Rajbari district, Bangladesh," American-Eurasian Journal of Sustainable Agriculture, vol. 5, no. 2, pp. 226-232, 2011.

[159] M. M. Rashid, F. B. Rafique, N. Debnath et al., "Medicinal plants and formulations of a community of the Tonchongya tribe in Bandarban district of Bangladesh," American-Eurasian Journal of Sustainable Agriculture, vol. 6, pp. 292-298, 2012.

[160] O. Lense, "The wild plants used as traditional medicines by indigenous people of Manokwari, West Papua," BioDiversitas, vol. 13, pp. 98-106, 2012.

[161] A. Kaushik, C. Jijta, J. J. Kaushik, R. Zeray, A. Ambesajir, and L. Beyene, "FRAP (ferric reducing ability of plasma) assay and effect of Diplazium esculentum (Retz) Sw. (a green vegetable of North India) on central nervous system," Indian Journal of Natural Products and Resources, vol. 3, pp. 228-231, 2012.

[162] S. Choudhury, P. Sharma, M. D. Choudhury, and G. D. Sharma, "Ethnomedicinal plants used by Chorei tribes of Southern Assam, North Eastern India," Asian Pacific Journal of Tropical Disease, vol. 2, supplement 1, pp. S141-S147, 2012.

[163] S. D. Rout, T. Panda, and N. Mishra, "Ethno-medicinal plants used to cure different diseases by tribals of mayurbhanj district of north Orissa," Studies on Ethno-Medicine, vol. 3, no. 1, pp. 2732, 2009.

[164] A. K. Das, B. K. Dutta, and G. D. Sharma, "Medicinal plants used by different tribes of Cachar district, Assam," Indian Journal of Traditional Knowledge, vol. 7, pp. 446-454, 2008.

[165] M. H. Khan and P. S. Yadava, "Antidiabetic plants used in Thoubal district of Manipur, Northeast India," Indian Journal of Traditional Knowledge, vol. 9, no. 3, pp. 510-514, 2010.

[166] H. B. Das, K. Majumdar, B. K. Datta, and D. Ray, "Ethnobotanical uses of some plants by Tripuri and Reang tribes of Tripura," Natural Product Radiance, vol. 8, no. 2, pp. 172-180, 2009.

[167] H. N. Thatoi, S. K. Panda, S. K. Rath, and S. K. Dutta, "Antimicrobial activity and ethnomedicinal uses of some medicinal plants from Similipal Biosphere Reserve, Orissa," Asian Journal of Plant Sciences, vol. 7, no. 3, pp. 260-267, 2008.

[168] M. Rahmatullah, M. N. K. Azam, Z. Khatun et al., "Medicinal plants used for treatment of diabetes by the Marakh sect of the Garo tribe living in Mymensingh district, Bangladesh," The African Journal of Traditional, Complementary and Alternative Medicines, vol. 9, pp. 380-385, 2012.

[169] N. Jahan, A. Khan, M. N. Hasan et al., "Ethnomedicinal plants of fifteen clans of the Garo tribal community of Madhupur in Tangail district, Bangladesh," American-Eurasian Journal of Sustainable Agriculture, vol. 7, pp. 188-195, 2013.

[170] S. Saharia and C. M. Sarma, "Ethno-medicinal studies on indigenous wetland plants in the tea garden tribes of Darrang and Udalguri district, Assam, India," NeBIO, vol. 2, pp. 27-33, 2011.

[171] S. K. Roy, U. K. Mazumder, and A. Islam, "Pharmacological evaluation of Enhydra fluctuans aerial parts for central nervous system depressant activity," Pharmacologyonline, vol. 1, pp. 632643, 2011.

[172] S. Sannigrahi, U. K. Mazumder, D. K. Pal, A. Mondal, and S. Roy, "Hepatoprotective potential of flavonoid rich fraction of Enhydra fluctuans against CCl4-induced oxidative damage in rats," Pharmacologyonline, vol. 2, pp. 575-586, 2009.

[173] S. Sannigrahi, U. K. Mazuder, D. K. Pal, S. Parida, and S. Jain, "Antioxidant potential of crude extract and different fractions of Enhydra fluctuans Lour," Iranian Journal of Pharmaceutical Research, vol. 9, no. 1, pp. 75-82, 2010.
[174] J. W. Prakash, R. D. A. Raja, N. A. Anderson et al., "Ethnomedicinal plants used by Kani tribes of Agasthiyarmalai biosphere reserve, southern Western Ghats," Indian Journal of Traditional Knowledge, vol. 7, pp. 410-413, 2008.

[175] M. Rahmatullah, D. Ferdausi, M. A. H. Mollik, R. Jahan, M. H. Chowdhury, and W. M. Haque, "A survey of medicinal plants used by Kavirajes of Chalna area, Khulna district, Bangladesh," The African Journal of Traditional, Complementary and Alternative Medicines, vol. 7, no. 2, pp. 91-97, 2010.

[176] A. N. Korpenwar, "Ethnomedicinal plants used by the tribal's in cure of wounds in Buldhana district (MS) India," International Journal of Recent Trends in Science and Technology, vol. 3, pp. 49-53, 2012.

[177] S. V. Patil and A. S. Bhuktar, "Diversity of ethnomedicinal plants from Jalgaon district of North Maharashtra," Trends in Life Science, vol. 1, pp. 34-37, 2012.

[178] M. Ali and N. Chaudhary, "Ficus hispida Linn.: a review of its pharmacognostic and ethnomedicinal properties," Pharmacognosy Reviews, vol. 5, no. 9, pp. 96-102, 2011.

[179] A. Panda and M. K. Misra, "Ethnomedicinal survey of some wetland plants of south orissa and their conservation," Indian Journal of Traditional Knowledge, vol. 10, no. 2, pp. 296-303, 2011.

[180] M. Rahmatullah, M. R. Haque, S. K. Islam et al., “A survey on the use of medicinal plants by folk medicinal practitioners in three areas of Pirojpur District, Bangladesh," AmericanEurasian Journal of Sustainable Agriculture, vol. 4, no. 2, pp. 247259, 2010.

[181] S. Pattanayak, M. K. Dutta, P. K. Debnath, S. K. Bandyopadhyay, B. Saha, and D. Maity, "A study on ethno-medicinal use of some commonly available plants for wound healing and related activities in three southern districts of West Bengal, India," Exploratory Animal and Medical Research, vol. 2, pp. 97-110, 2012.

[182] S. K. Sahu, D. Das, N. K. Tripathy, S. C. Dinda, and H. K. S. Kumar, "Pharmacognostical and physico-chemical studies on the leaf of Glinus oppositifolius L," Der Pharmacia Lettre, vol. 4, pp. 1495-1500, 2012.

[183] N. Hoque, M. Z. Imam, S. Akter et al., "Antioxidant and antihyperglycemic activities of methanolic extract of Glinus oppositifolius leaves," Journal of Applied Pharmaceutical Science, vol. 1, pp. 50-53, 2011.

[184] R. B. Kumar and B. Suryanarayana, "Ethnomedicinal recipes for skin and dermatitis \& allied diseases from tribals of Sriharikota Island, Andhra Pradesh," Journal of Pharmacognosy and Phytochemistry, vol. 2, pp. 197-212, 2013.

[185] P. K. Singh, V. Kumar, R. K. Tiwari, A. Sharma, C. V. Rao, and R. H. Singh, "Medico-Ethnobotany of "Chatara" block of District Sonebhadra, Uttar Pradesh, India," Advanced Biology Research, vol. 4, pp. 65-80, 2010.

[186] M. N. Manvar and T. R. Desai, "Phytochemical and pharmacological profile of Ipomoea aquatica," Indian Journal of Medical Sciences, vol. 67, pp. 49-60, 2013.

[187] F. O. Omotayo and T. I. Borokini, "Comparative phytochemical and ethnomedicinal survey of selected medicinal plants in Nigeria," Scientific Research and Essays, vol. 7, pp. 989-999, 2012.

[188] M. Giday, Z. Asfaw, Z. Woldu, and T. Teklehaymanot, "Medicinal plant knowledge of the Bench ethnic group of Ethiopia: an ethnobotanical investigation," Journal of Ethnobiology and Ethnomedicine, vol. 5, pp. 34-43, 2009. 
[189] A. Kar and S. K. Borthakur, "Wild vegetables of KarbiAnglong district, Assam," Natural Product Radiance, vol. 7, no. 5, pp. 448-460, 2008.

[190] T. I. Borokini, D. A. Ighere, M. Clement, T. O. Ajiboye, and A. A. Alowonle, "Ethnobiological durvey of traditional medicine practices in Oyo State," Journal of Medicinal Plants Studies, vol. 1, pp. 1-16, 2013.

[191] S. O. Ogundele, "Aspects of indigenous medicine in South Western Nigeria," Ethno-Medicine, vol. 1, pp. 127-133, 2007.

[192] V. Panda and M. Sonkamble, "Phytochemical constituents and pharmacological activities of Ipomoea batatas L., (Lam)-a review," International Journal of Research in Phytochemistry and Pharmacology, vol. 2, pp. 25-34, 2012.

[193] C. Muthu, M. Ayyanar, N. Raja, and S. Ignacimuthu, "Medicinal plants used by traditional healers in Kancheepuram District of Tamil Nadu, India," Journal of Ethnobiology and Ethnomedicine, vol. 2, pp. 43-52, 2006.

[194] M. Mukti, A. Ahmed, S. Chowdhury et al., "Medicinal plant formulations of Kavirajes in several areas of Faridpur and Rajbari districts, Bangladesh," American-Eurasian Journal of Sustainable Agriculture, vol. 6, pp. 234-247, 2012.

[195] M. Rahmatullah, M. A. H. Mollik, A. K. Paul et al., "A comparative analysis of medicinal plants used to treat gastrointestinal disorders in two sub-districts of greater Khulna division, Bangladesh," Advances in Natural and Applied Sciences, vol. 4, no. 1, pp. 22-28, 2010.

[196] M. S. Hossan, P. Roy, S. Seraj et al., "Ethnomedicinal knowledge among the Tonchongya tribal community of Roangchaari Upazila of Bandarban district, Bangladesh," American-Eurasian Journal of Sustainable Agriculture, vol. 6, pp. 349-359, 2012.

[197] R. Sivaranjani and K. Ramakrishnan, "Traditional uses of medicinal plants in treating skin diseases in Nagapattinam district of Tamil Nadu, India," International Research Journal of Pharmacy, vol. 3, pp. 201-204, 2012.

[198] C. Alagesaboopathi, "Ethnomedicinal plants and their utilization by villagers in Kumaragiri Hills of Salem district of Tamilnadu, India," African Journal of Traditional, Complementary and Alternative Medicines, vol. 6, no. 3, pp. 222-227, 2009.

[199] R. Srinivasan, B. Ravali, P. Suvarchala, A. Honey, A. Tejaswini, and P. Neeraja, "Leucas aspera-medicinal plant: a review," International Journal of Pharma and Bio Sciences, vol. 2, no. 2, pp. 153-159, 2011.

[200] G. Singh and G. S. Rawat, "Ethnomedicinal survey of Kedarnath Wildlife Sanctuary in Western Himalaya, India," Indian Journal of Fundamental and Applied Life Sciences, vol. 1, pp. 35-46, 2011.

[201] H. Yineger, E. Kelbessa, T. Bekele, and E. Lulekai, "Plants used in traditional management of human ailments at Bale Mountains National Park, Southeastern Ethiopia," Journal of Medicinal Plants Research, vol. 2, pp. 132-153, 2008.

[202] P. K. Samal, P. P. Dhyani, and M. Dollo, "Indigenous medicinal practices of Bhotia tribal community in Indian Central Himalaya," Indian Journal of Traditional Knowledge, vol. 9, no. 1, pp. 140-144, 2010.

[203] M. Bnouham, A. Ziyyat, H. Mekhfi, A. Tahri, and A. Legssyer, "Medicinal plants with potential antidiabetic activity-a review of ten years of herbal medicine research (1990-2000)," International Journal of Diabetes and Metabolism, vol. 14, no. 1, pp. 1-25, 2006.

[204] S. Ganesan, N. R. Pandi, and N. Banumathy, "Ethnomedicinal survey of Alagarkoil Hills (Reserved forest), Tamil Nadu, India," EJournal of Indian Medicine, vol. 1, pp. 1-18, 2007-2008.
[205] K. Kumar and S. G. Abbas, "Ethnomedicinal composition depends upon floristic composition: a case studied in Sal forests of Jharkand," International Journal of Pharmaceutical and Life Sciences, vol. 3, pp. 1710-1719, 2012.

[206] K. Upreti, J. S. Jalal, L. M. Tewari, G. C. Joshi, Y. P. S. Pangtey, and G. Tewari, "Ethnomedicinal uses of Pteridophytes of Kumaun Himalaya, Uttarakhand, India," The Journal of American Science, vol. 5, pp. 167-170, 2009.

[207] P. Parihar and L. Parihar, "Some pteridophytes of medicinal importance from Rajasthan," Natural Product Radiance, vol. 5, pp. 297-301, 2006.

[208] M. Rahmatullah, A. A. B. T. Kabir, M. M. Rahman et al., "Ethnomedicinal practices among a minority group of Christians residing in Mirzapur village of Dinajpur district, Bangladesh," Advances in Natural and Applied Sciences, vol. 4, no. 1, pp. 45$51,2010$.

[209] N. K. Sharma, "Ethnomedicinal studies on ferns and fern allies of Hadoti Plateau, southeastern Rajasthan," Zoos' Print Journal, vol. 17, no. 3, pp. 732-734, 2002.

[210] P. Praneetha, V. S. Rani, and B. R. Kumar, "Hepatoprotective activity of methanolic extract of leaves of Marsilea minuta Linn against CCl4 induced hepatic damage in rats," Global Journal of Pharmacology, vol. 5, pp. 164-171, 2011.

[211] O. P. Tiwari, S. K. Bhattamisra, P. N. Singh, and V. Kumar, "Adaptogenic anti-stress activity of standardised extract of Marselia minuta L," Pharmacologyonline, vol. 1, pp. 290-299, 2009.

[212] R. Chakraborty, B. De, N. Devanna, and S. Sen, "Antitussive, expectorant activity of Marsilea minuta L., an Indian vegetable," Journal of Advanced Pharmaceutical Technology and Research, vol. 4, pp. 61-64, 2013.

[213] S. Madhu, V. Kannabirran, P. R. Frank, M. S. Reddy, and N. Gnanasekar, "Evaluation of anti diabetic activity of Marsilea minuta Linn against alloxan induced diabetes in albino rats," International Research Journal of Pharmacy, vol. 3, pp. 223-225, 2012.

[214] O. P. Tiwari, S. K. Bhattamisra, P. K. Tripathi, and P. N. Singh, "Anti-aggressive activity of a standardized extract of Marsilea minuta Linn. in rodent models of aggression," Bioscience Trends, vol. 4, no. 4, pp. 190-194, 2010.

[215] M. A. Q. Sarker, P. C. Mondol, M. J. Alam, M. S. Parvez, and M. F. Alam, "Comparative study on antitumor activity of three pteridophytes ethanol extracts," Journal of Agricultural Technology, vol. 7, pp. 1661-1671, 2011.

[216] E. Amri and D. P. Kisangau, "Ethnomedicinal study of plants used in villages around Kimboza forest reserve in Morogoro, Tanzania," Journal of Ethnobiology and Ethnomedicine, vol. 8, article 1, 9 pages, 2012.

[217] N. P. Rajith, D. V. Ambily, V. M. Dan, P. S. Devi, V. George, and P. Pushpangadan, "A survey on ethnomedicinal plants used for menstrual disorders in Kerala," Indian Journal of Traditional Knowledge, vol. 11, pp. 453-460, 2012.

[218] M. Jose, B. Bhagya, and M. Shantaram, "Ethnomedicinal herbs used in oral health and hygiene in Coastal Dakshina Kannada," Journal of Oral Health and Community Dentistry, vol. 5, pp. 119123, 2011.

[219] A. R. Chowdhury and M. Rahmatullah, "Ethnomedicinal plants for treatment of jaundice by the folk and tribal medicinal practitioners of several districts in Bangladesh and review of their scientifically reported hepatoprotective activity," AmericanEurasian Journal of Sustainable Agriculture, vol. 6, pp. 360-370, 2012. 
[220] Z. Khatun, P. Bhuiyan, M. S. I. Roney, and M. Rahmatullah, "Traditional knowledge on zootherapeutic practices among some folk medicinal practitioners of Bangladesh," AmericanEurasian Journal of Sustainable Agriculture, vol. 7, pp. 155-161, 2013.

[221] M. E. K. Shaheen, M. A. Syef, S. S. Saha et al., "Medicinal plants used by the folk and tribal medicinal practitioners in two villages of Khakiachora and Khasia Palli in Sylhet district, Bangladesh," Advances in Natural and Applied Sciences, vol. 5, no. 1, pp. 9-19, 2010.

[222] M. Rahmatullah, Z. Khatun, A. Hasan et al., "Survey and scientific evaluation of medicinal plants used by the Pahan and Teli tribal communities of Natore district, Bangladesh," The African Journal of Traditional, Complementary and Alternative Medicines, vol. 9, pp. 366-373, 2012.

[223] B. R. Goyal, B. B. Agrawal, R. K. Goyal, and A. A. Mehta, "Phytopharmacology of Moringa oleifera Lam.- - an overview," Natural Product Radiance, vol. 6, no. 4, pp. 347-353, 2007.

[224] J. O. Erhabor, M. Idu, and F. O. Udo, "Ethnomedicinal survey of medicinal plants used in the treatment of male infertility among the IFA Nkari people of Ini Local Government Area of Akwa Ibom State, Nigeria," Research Journal of Recent Sciences, vol. 2, pp. 5-11, 2013.

[225] H. E. Gangte, G. T. Zomi, and N. S. Thoudam, "Ethnomedicinal plants used in diarrhoea and dysentery by the Zou tribe in Churachandpur district, Manipur, India," Asian Journal of Experimental Biological Sciences, vol. 4, pp. 369-376, 2013.

[226] L. Jinu and K. J. Chandra, "A study on ethnomedicinal uses of plants in Dhemaji district of Assam with special reference to reproductive health," International Research Journal of Pharmacy, vol. 4, pp. 261-263, 2013.

[227] M. Z. Imam and S. Akter, "Musa paradisiaca L. and Musa sapientum L.: a phytochemical and pharmacological review," Journal of Applied Pharmaceutical Science, vol. 1, pp. 14-20, 2011.

[228] A. C. Ene and S. E. Atawodi, "Ethnomedicinal survey of plants used by the Kanuris of North-Eastern Nigeria," Indian Journal of Traditional Knowledge, vol. 11, pp. 640-645, 2012.

[229] W. Gritsanapan, "Ethnomedicinal plants popularly used in Thailand as laxative drugs," in Ethnomedicine: A Source of Complementary Therapeutics, D. Chattopadhyay, Ed., pp. 295315, Research Signpost, Kerala, India, 2010.

[230] T. O. Elufioye, A. T. Oladele, C. M. Cyril-Olutayo, J. M. Agbedahunsi, and S. A. Adesanya, "Ethnomedicinal study and screening of plants used for memory enhancement and antiaging in Sagamu, Nigeria," European Journal of Medicinal Plants, vol. 2, pp. 262-275, 2012.

[231] M. Rahmatullah, A. K. Das, M. A. H. Mollik et al., "An ethnomedicinal survey of Dhamrai Sub-district in Dhaka district, Bangladesh," American-Eurasian Journal of Sustainable Agriculture, vol. 3, pp. 881-888, 2009.

[232] J. O. Igoli, O. G. Ogaji, T. A. Tor-Anyiin, and N. P. Igoli, “Traditional medicine practice amongst the Igede people of Nigeria. Part II," The African Journal of Traditional, Complementary and Alternative Medicines, vol. 2, pp. 134-152, 2005.

[233] Y. A. Ahirrao and D. A. Patil, "Ethnomedicinal claims against stomach complaints in Buldhana district (Maharashtra, India)," Life Sciences Leaflets, vol. 1, pp. 16-25, 2012.

[234] R. Muralidharan and D. Narasimhan, "Ethnomedicinal plants used against gastrointestinal problem in Gingee Hills of Villupuram district, Tamil Nadu," Journal of Applied Pharmaceutical Science, vol. 2, pp. 123-125, 2012.
[235] N. R. Mehta, P. Ekta, P. Pragnesh, V. Patani, and B. Shah, "Nelumbo nucifera (lotus): a review on ethnobotany, phytochemistry and pharmacology," Indian Journal of Pharmaceutical and Biological Research, vol. 1, pp. 152-167, 2013.

[236] D. P. Ghorband and S. D. Biradar, "Folk medicine used by the tribes of Kinwat forest of Nanded district, Maharashtra, India," Indian Journal of Natural Products and Resources, vol. 3, no. 1, pp. 118-122, 2012.

[237] C. R. Sahu, R. K. Nayak, and N. K. Dhal, “Traditional herbal remedies for various diseases used by tribals of Boudh district, Odisha, India. For sustainable development," International Journal of Herbal Medicine, vol. 1, pp. 12-20, 2013.

[238] A. Kumar, D. D. Tewari, and J. P. Tewari, "Ethnomedicinal knowledge among Tharu tribe of Devipatan division," Indian Journal of Traditional Knowledge, vol. 5, pp. 310-313, 2006.

[239] M. Muthulingam, "Antihepatotoxic efficacy of Nyphaea pubescens (Willd.) on acetaminophen induced liver damage in male Wistar rats," International Journal of Current Research, vol. 3, pp. 12-16, 2010.

[240] E. Selvakumari, S. Shantha, P. T. Purushoth, and C. Sreenathkumar, "Antiproliferative activity of ethanolic flower extract from Nyphaea pubescens Willd against human cervical and breast carcinoma in vitro," International Research Journal of Pharmacy, vol. 3, pp. 124-125, 2012.

[241] D. Kalita and B. Phukan, "Some ethnomedicines used by the Tai Ahom of Dibrugarh district, Assam, India," Indian Journal of Natural Products and Resources, vol. 1, no. 4, pp. 507-511, 2010.

[242] S. S. Hebbar, V. H. Harsha, V. Shripathi, and G. R. Hegde, "Ethnomedicine of Dharwad district in Karnataka, Indiaplants used in oral health care," Journal of Ethnopharmacology, vol. 94, no. 2-3, pp. 261-266, 2004.

[243] M. Mukti, M. A. Rahman, A. B. M. A. Bashar, S. Hossain, and M. Rahmatullah, "Medicinal plants of the Khatriya and Kashya clans of the Bagdi people of Rajbari district in Bangladesh," American-Eurasian Journal of Sustainable Agriculture, vol. 7, pp. 170-177, 2013.

[244] M. Srikanth, T. Swetha, and B. Veeresh, "Phytochemistry and pharmacology of Oxalis corniculata Linn.: a review," International Journal of Pharmaceutical Sciences and Research, vol. 3, pp. 4077-4085, 2012.

[245] Z. B. Rahim, M. M. Rahman, D. Saha, S. M. Z. Hosen, S. Paul, and S. Kader, "Ethnomedicinal plants used against jaundice in Bangladesh and its economical prospects," Bulletin of Pharmaceutical Research, vol. 2, pp. 91-105, 2012.

[246] M. L. Leporatti and K. Ghedira, "Comparative analysis of medicinal plants used in traditional medicine in Italy and Tunisia," Journal of Ethnobiology and Ethnomedicine, vol. 5, pp. 31-38, 2009.

[247] K. Singh, S. Gupta, and P. K. Mathur, "Investigation on ethnomedicinal plants of District Firozabad," Journal of Advanced Laboratory Research in Biology, vol. 1, pp. 64-66, 2010.

[248] M. Ishtiaq, W. Hanif, M. A. Khan, M. Ashraf, and A. M. Butt, "An ethnomedicinal survey and documentation of important medicinal folklore food phytonims of flora of Samahni valley, (Azad Kashmir) Pakistan," Pakistan Journal of Biological Sciences, vol. 10, no. 13, pp. 2241-2256, 2007.

[249] S. Pawar and D. A. Patil, "Traditional herbal ethnomedicinal recipes in Jalgaon district (M.S.): a resume," Life Sciences Leaflets, vol. 3, pp. 12-16, 2012.

[250] D. P. Ghorband and S. D. Biradar, "Traditional medicines knowledge in Dharmabad taluka of Nanded District, 
Maharashtra, India," Indian Journal of Natural Products and Resources, vol. 2, no. 4, pp. 498-503, 2011.

[251] B. L. Punjani, "Herbal folk medicines used for urinary complaints in tribal pockets of northeast Gujarat," Indian Journal of Traditional Knowledge, vol. 9, no. 1, pp. 126-130, 2010.

[252] A. R. Sahu, N. Behera, and S. P. Mishra, "Use of ethnomedicinal plants by natives of bargarh district of Orissa, India," Ethnobotanical Leaflets, vol. 14, pp. 889-910, 2010.

[253] T. T. Sham, A. C. Y. Yuen, Y. F. Ng, C. O. Chan, D. K. W. Mok, and S. W. Chan, "A review of the phytochemistry and pharmacological activities of Raphani semen," Evidence-Based Complementary and Alternative Medicine, vol. 2013, Article ID 636194, 16 pages, 2013.

[254] A. Chantia, "Traditional knowledge of ethnomedicine in Jaunsar-bawar, Dehradun district," Indian Journal of Traditional Knowledge, vol. 2, pp. 397-399, 2003.

[255] A. Tomar, "Folk medicinal uses of plant roots from Meerut district, Uttar Pradesh," Indian Journal of Traditional Knowledge, vol. 8, pp. 298-301, 2009.

[256] M. Sathya and R. Kokilavani, "Effect of ethanolic root extract of Saccharum spontaneum Linn. against calculi producing diet induced urolithiasis," Asian Journal of Pharmaceutical and Biological Research, vol. 2, pp. 157-160, 2012.

[257] M. Khalid, H. H. Siddiqui, and S. Freed, "Free radical scavenging and total phenolic content of Saccharum spontaneum L. root extracts," International Journal of Research in Pharmacy and Chemistry, vol. 1, pp. 1160-1166, 2011.

[258] C. Lans, "Comparison of plants used for skin and stomach problems in Trinidad and Tobago with Asian ethnomedicine," Journal of Ethnobiology and Ethnomedicine, vol. 3, pp. 3-14, 2007.

[259] M. Rahmatullah, M. A. H. Mollik, A. T. M. A. Azam et al., "Ethnobotanical survey of the Santal tribe residing in Thakurgaon district, Bangladesh," American-Eurasian Journal of Sustainable Agriculture, vol. 3, pp. 889-898, 2009.

[260] B. Thomas and A. Rajendran, "Less known ethnomedicinal plants used by Kurichar tribe of Wayanad district, Southern Western Ghats Kerala, India," Botany Research International, vol. 6, pp. 32-35, 2013.

[261] J. Barukial and J. N. Sarmah, "Ethnomedicinal plants used by the people of Golaghat district, Assam, India," International Journal of Medicinal and Aromatic Plants, vol. 1, pp. 203-211, 2011.

[262] M. N. Sarker, A. A. Mahin, S. Munira et al., "Ethnomedicinal plants of the Pankho community of Bilaichari Union in Rangamati district, Bangladesh," American-Eurasian Journal of Sustainable Agriculture, vol. 7, pp. 114-120, 2013.

[263] S. R. Kunjam, S. K. Jadhav, and K. L. Tiwari, “Traditional herbal medicines for the treatment of snake bite and scorpion sting by the tribes of South Surguja, Chhattisgarh, India," Medicinal and Aromatic Plants, vol. 2, pp. 120-122, 2013.

[264] M. Ayyanar and S. Ignacimuthu, "Herbal medicines for wound healing among tribal people in Southern India: ethnobotanical and scientific evidences," International Journal of Applied Research in Natural Products, vol. 2, pp. 29-42, 2009.

[265] S. K. Rai, "Medicinal plants used by Meche people of Jhapa district, Eastern Nepal," Our Nature, vol. 2, pp. 27-32, 2004.

[266] K. Murti, M. Panchal, P. Taya, and R. Singh, "Pharmacological properties of Scoparia dulcis: a review," Pharmacologia, vol. 3, pp. 344-347, 2012.

[267] C. Alagesaboopathi and K. Rajendran, "Ethnomedicinal plants of Sirumalai Hills of Dindigul District, Tamil Nadu, India," Ethnobotanical Leaflets, vol. 13, pp. 159-164, 2009.
[268] S. Sudeesh, "Ethnomedicinal plants used by Malayaraya tribes of Vannapuram village in Idukki, Kerala, India," Indian Journal of Scientific Research and Technology, vol. 1, pp. 7-11, 2012.

[269] R. D. Kshirsagar and N. P. Singh, "Some less known ethnomedicinal uses from Mysore and coorg districts, Karnataka, Southern India," Ancient Science of Life, vol. 20, pp. 20-25, 2001.

[270] M. Ayyanar and S. Ignacimuthu, "Ethnobotanical survey of medicinal plants commonly used by Kani tribals in Tirunelveli hills of Western Ghats, India," Journal of Ethnopharmacology, vol. 134, no. 3, pp. 851-864, 2011.

[271] A. Poongodi, S. Thilagavathi, V. Aravindhan, and A. Rajendran, "Observations on some ethnomedicinal plants in Sathyamangalam forests of Erode district, Tamil Nadu, India," Journal of Medicinal Plant Research, vol. 5, no. 19, pp. 4709-4714, 2011.

[272] S. Kashyap and S. Mishra, "Phytopharmacology of Indian plant Sesbania grandiflora L," Journal of Psychopharmacology, vol. 1, pp. 63-75, 2012.

[273] N. Gibji, N. Ringu, and N. O. Dai, "Ethnomedicinal knowledge among the Adi tribes of Lower Dibang Valley district of Arunachal Pradesh, India," International Research Journal of Pharmacy, vol. 3, pp. 223-229, 2012.

[274] N. L. Pfoze, Y. Kumar, and B. Myrboh, "Survey and assessment of ethnomedicinal plants used in Senapati district of Manipur State, Northeast India," Phytopharmacology, vol. 2, pp. 285-311, 2012.

[275] C. P. Kala, "Ethnomedicinal botany of the Apatani in the Eastern Himalayan region of India," Journal of Ethnobiology and Ethnomedicine, vol. 1, pp. 11-18, 2005.

[276] S. Dubey, S. Maity, M. Singh, S. A. Saraf, and S. Saha, "Phytochemistry, pharmacology and toxicology of Spilanthes acmella: a review," Advances in Pharmacological Sciences, vol. 2013, Article ID 423750, 9 pages, 2013. 


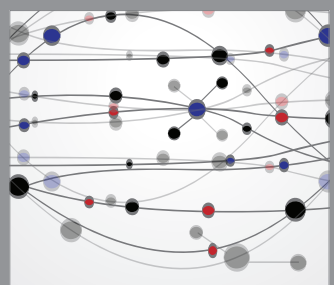

The Scientific World Journal
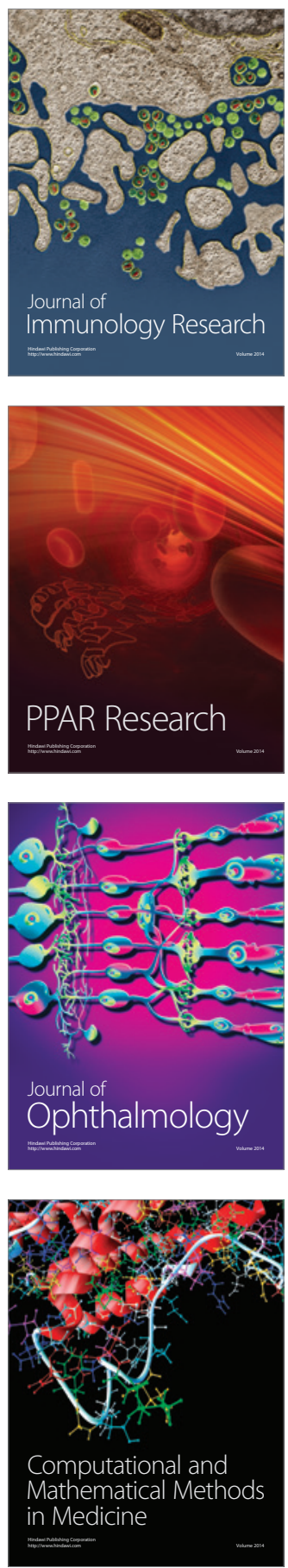

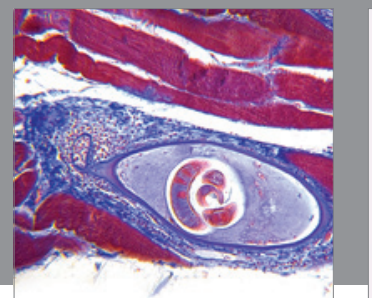

Gastroenterology

Research and Practice
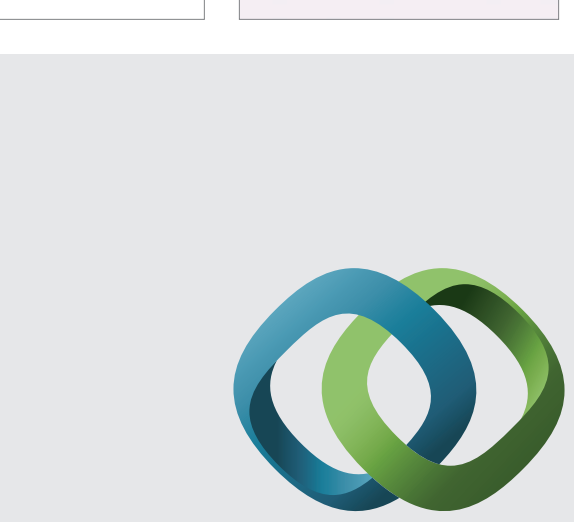

\section{Hindawi}

Submit your manuscripts at

http://www.hindawi.com
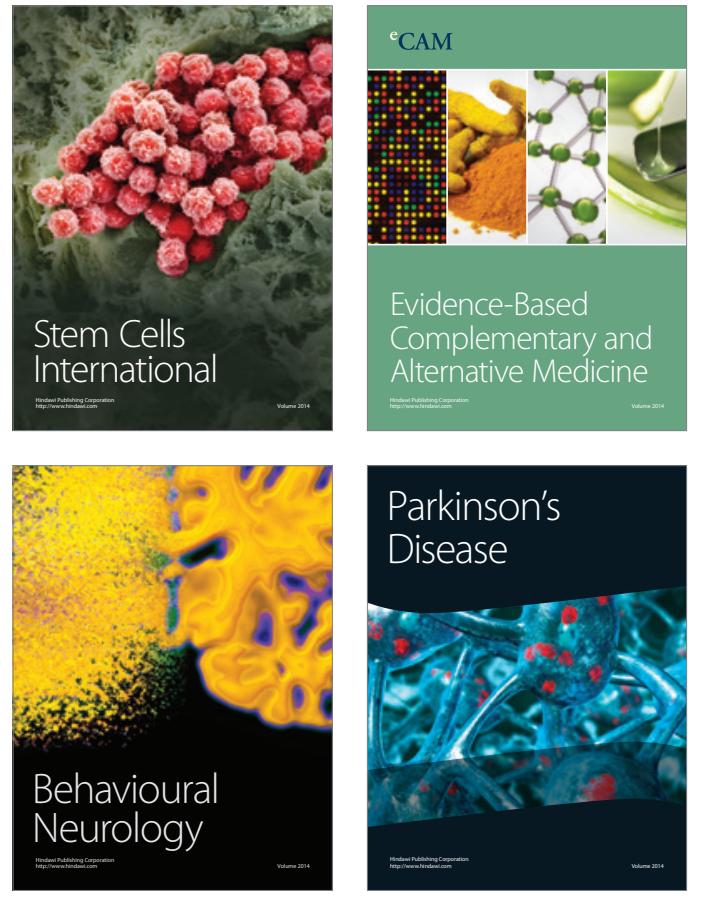


Disease Markers
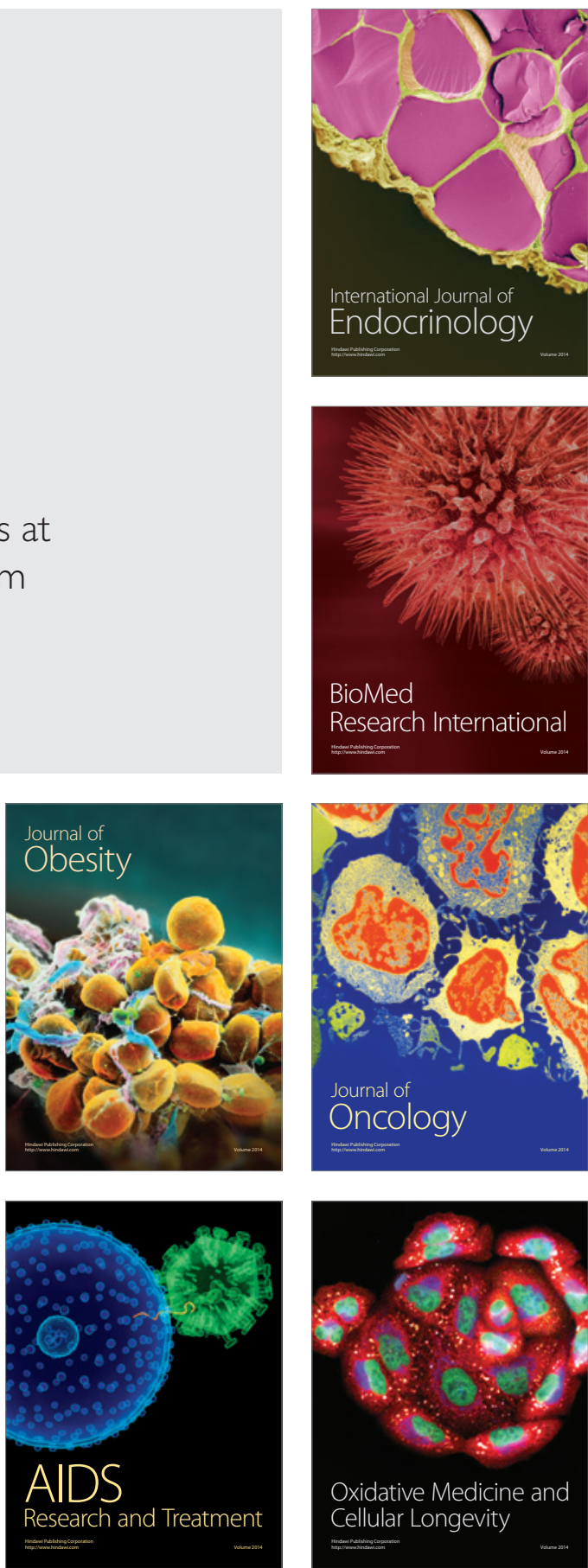